\title{
13. UPPERMOST JURASSIC TO LOWER CRETACEOUS DEEP-WATER BENTHIC FORAMINIFERAL ASSEMBLAGES FROM SITE 765 ON THE ARGO ABYSSAL PLAIN ${ }^{1}$
}

\author{
Michael A. Kaminski, ${ }^{2}$ Felix M. Gradstein, ${ }^{3}$ and Stanislaw Geroch ${ }^{4}$
}

\begin{abstract}
Benthic foraminifers were studied in 99 samples collected from the lower $200 \mathrm{~m}$ of Hole $765 \mathrm{C}$. The studied section ranges from the Tithonian to Aptian, and benthic foraminifers can be subdivided into five assemblages on the basis of faunal diversity and stratigraphic ranges of distinctive species. Compared with deep-water assemblages from Atlantic DSDP sites and Poland, assemblages from the Argo Abyssal Plain display a higher diversity of agglutinated forms, which comprise the autochthonous assemblages. Assemblages at the base of Hole $765 \mathrm{C}$ are wholly composed of agglutinated forms, reflecting deposition beneath the carbonate compensation depth (CCD). Most calcareous benthic species are found in turbidite layers, and the presence of an upper Valanginian Praedorothia praehauteriviana Assemblage may indicate deposition at or just below the CCD. The $P$. praehauteriviana Assemblage from Hole $765 \mathrm{C}$ is the temporal equivalent of similar assemblages from DSDP Holes 534A, 416A, 370, 105, and 101 in the Atlantic Ocean and Hole 306 in the Pacific Ocean. Stratigraphic ranges of cosmopolitan agglutinated species at Site 765 generally overlap with their reported ranges in the Atlantic and in the bathyal flysch sequences of the Carpathians; however, several species from Hole $765 \mathrm{C}$ have not been previously reported from Uppermost Jurassic to Lower Cretaceous abyssal sediments.
\end{abstract}

\section{INTRODUCTION}

The Argo Abyssal Plain is an extremely flat abyssal plain about $5700 \mathrm{~m}$ deep, located off the continental margin of northwestern Australia. This plain is underlain by the oldest oceanic crust known in the Indian Ocean. In comparison to the Atlantic margins, the northwestern Australian margin and Argo Abyssal Plain are starved of sediment, owing in part to Australia's low relief and dry climate. Previous drilling during DSDP Leg 27 and more recent geophysical surveys by the Australian Bureau of Mineral Resources have indicated that the sedimentary sequences in the southern region of the Argo Abyssal Plain have been condensed to a total thickness of less than $1000 \mathrm{~m}$. As a result, the oldest submarine strata overlying basement were expected to be relatively unaltered by overburden diagenesis and well within reach of deep-sea drilling. Thus, a major objective of Leg 123 was to obtain a high-quality, continuously cored sedimentary record for studying Mesozoic magnetobiostratigraphy, paleoceanography, and deep-sea paleoecology.

Since the inception of the Deep Sea Drilling Project and the Ocean Drilling Program, fewer than one dozen DSDP/ODP holes have yielded sediments older than about $140 \mathrm{Ma}$, and the majority of these sites are situated in the North Atlantic Ocean. As a result, much of our knowledge of the oldest abyssal benthic foraminiferal assemblages from the world's oceans is necessarily based on the Uppermost Jurassic to Lower Cretaceous Cat Gap and Blake-Bahama formations and their lateral equivalents (Luterbacher, 1972; Maync, 1973; Kuznetsova and Seibold, 1977; Sliter, 1980; Gradstein, 1983). These formations consist largely of calcareous lithofacies, which testifies to a relatively deep CCD in the North Atlantic at the time (Jansa et al., 1979). Lithofacies and biofacies

\footnotetext{
${ }^{1}$ Gradstein, F. M., Ludden, J. N., et al., 1992. Proc. ODP, Sci. Results, 123: College Station, TX (Ocean Drilling Program).

Department of Geological Sciences, University Collge, London, Gower Street, London, WCIE 6BT, U.K. and Department of Paleoceanography, GEOMAR, Wischhofstrasse 1-3, D-2300 Kiel 14, F.R.G.

${ }^{3}$ Geological Survey of Canada, Bedford Institute of Oceanography, Dartmouth, Nova Scotia B3Y 4A2, Canada.

${ }^{4}$ Institute of Geological Sciences, Jagiellonian University, ul. Oleandry 2a, 30-063 Kraków, Poland.
}

typical of a sub-CCD environment are poorly represented in the North Atlantic.

The results of DSDP Leg 27 revealed a markedly different pattern of sedimentation on the Argo Abyssal Plain. The Uppermost Jurassic to Lowermost Cretaceous sediments recovered at DSDP Site 261 consist mainly of claystones deposited near or beneath the CCD. Biostratigraphic studies of the discontinuously cored sediments overlying ocean crust at Site 261 (Kuznetsova, 1974; Bartenstein, 1974) revealed that diverse and well-preserved assemblages, made up largely of deep-water agglutinated foraminifers (DWAF), are present in the region. Kuznetsova realized that the benthic assemblages from the base of Hole 261 were unique and remarked that "no directly comparable foraminiferal assemblages have been described from either the Indian Ocean or from remote areas of Europe, America, or Asia." More recently, Riegraf and Luterbacher (1989a) reexamined the benthic foraminifers from the base of Hole 261 in their summary of Lower Cretaceous benthic foraminifers from the first 79 DSDP legs. Apart from these reports from a single DSDP site, the nature of DWAF assemblages from truly abyssal Latest Jurassic to Early Cretaceous sub-CCD environments is still virtually unknown.

Drilling in the Argo Abyssal Plain during Leg 123 has made it possible for scientists to develop a relatively high-resolution biostratigraphy for this region. The primary goal of this investigation is to document the nature of the oldest deep-water benthic foraminiferal assemblages recovered at Site 765 , with special emphasis on the DWAF assemblages. We compare the biostratigraphic record of DWAF assemblages at Site 765 with published biostratigraphic data from DSDP sites in the Indian and Atlantic oceans and from coeval bathyal flysch sequences of the Polish Carpathians to evaluate the potential utility of Uppermost Jurassic to Lower Cretaceous DWAF assemblages for biostratigraphic correlation and studies of Tethyan paleobiogeography and paleoceanography.

\section{SAMPLE LOCALITY}

Site 765 is located at $15^{\circ} 58^{\prime} \mathrm{S}, 117^{\circ} 34^{\prime} \mathrm{E}$ at a depth of $5723 \mathrm{~m}$ on the Argo Abyssal Plain off northwestern Australia (Fig. 1). Site 765 was drilled into normal oceanic crust that formed during the Latest Jurassic, about $15 \mathrm{~km}$ seaward of the geophysical ocean/continent boundary that separates Australia from the Argo 


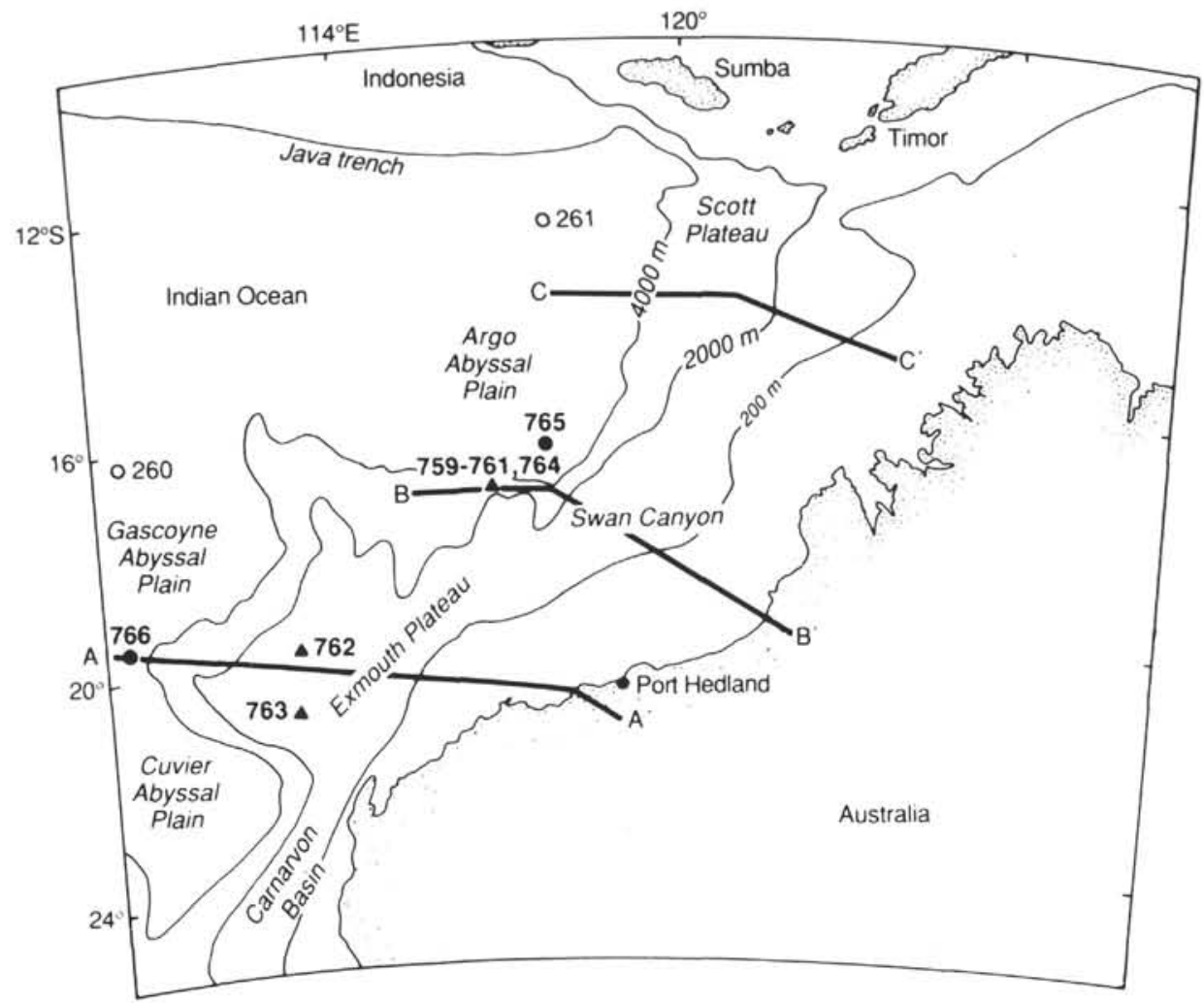

Figure 1. Location of DSDP/ODP Sites on the Argo Abyssal Plain.

Abyssal Plain. Site 765 is situated on basement assigned to marine magnetic anomaly M-26, which is the oldest magnetic anomaly in the Argo Abyssal Plain (Fullerton et al., 1989; Sager et al., this volume), indicating a late Oxfordian age for basement. Backtracking calculations indicate that the site underwent normal thermal subsidence and that Uppermost Jurassic to Lower Cretaceous sediments were deposited at an estimated depth of 2700 to $4700 \mathrm{~m}$ (Fig. 2).

Drilling in three holes at Site 765 penetrated a total of $931 \mathrm{~m}$ of sediment, which was subdivided into seven lithologic units by the Shipboard Scientific Party. For this study, we examined samples from lithologic Units V through VII that were recovered at the base of Hole $765 \mathrm{C}$. These units are described from oldest to youngest as follows:

Unit VII (892.9-931.2 mbsf). The Tithonian to lower Valanginian sediments at the base of Hole $765 \mathrm{C}$ consist of brown-red silty claystones and reddish-brown to greenish claystones with turbidite layers containing radiolarians and Inoceramus prisms. Altered volcanic ash layers occur in the upper portion of Unit VII and in overlying Unit VI.

Unit VI (859.2-892.9 mbsf). Valanginian to Hauterivian sediments consist of red claystones having varied minor lithologies, including calcareous turbidites, nannofossil chalk, and radiolarian turbidites.

Unit V (724.1-859.2 mbsf). Uppermost Hauterivian to Aptian sediments consist of varicolored and dark gray claystone with rhodochrosite, zeolites, and radiolarian sands deposited as turbidites.

The chronostratigraphy of the studied section has been constrained by palynomorphs, radiolarians, and calcareous nannofossils. The biostratigraphy of Hole $765 \mathrm{C}$ is supplemented by several magnetic polarity reversals that were identified near the top of the studied section. The combined magnetobiostratigraphic

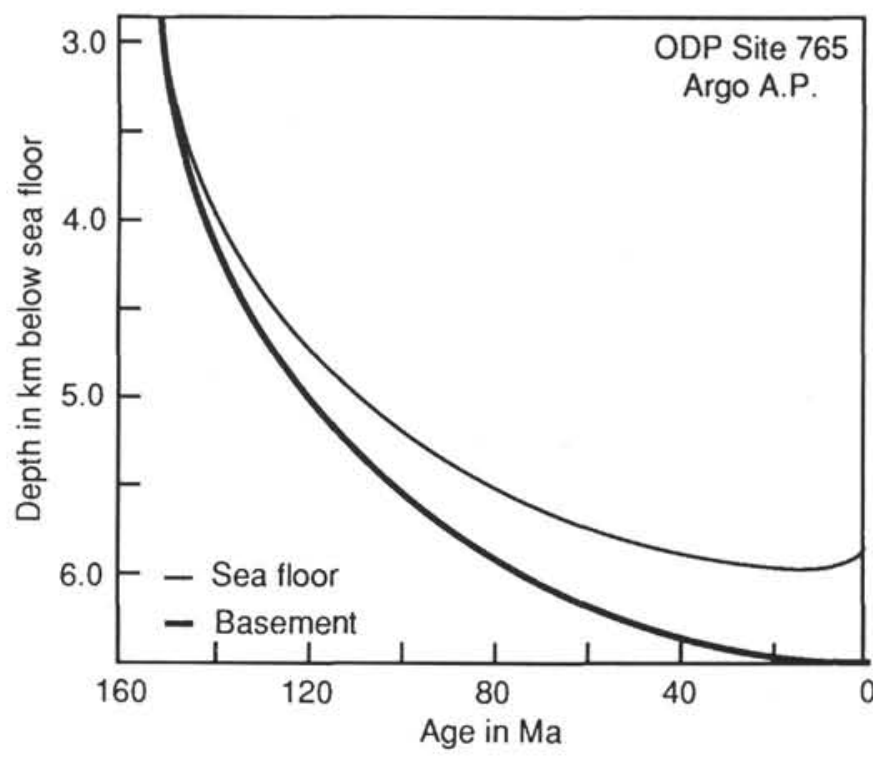

Figure 2. Subsidence history of Site 765, based on thermal subsidence calculations for normal oceanic crust (Sclater et al., 1985).

data were compiled to develop an age model for the lower $200 \mathrm{~m}$ of Hole 765C (Fig. 3, Table 1), which allows us to interpolate the positions of stage boundaries with an accuracy of 2 to $5 \mathrm{~m}$. Although the base of the sedimentary section in Hole $765 \mathrm{C}$ was originally described as mid-Berriasian, based on shipboard biostratigraphic analyses (Leg 123 Shipboard Scientific Party, 1989), more detailed analysis of nannofossils in Cores 123-765C-61R and $-62 R$ yields a Tithonian age, based on the occurrence of abundant, large Watznaueria manivitae, which correlates well 


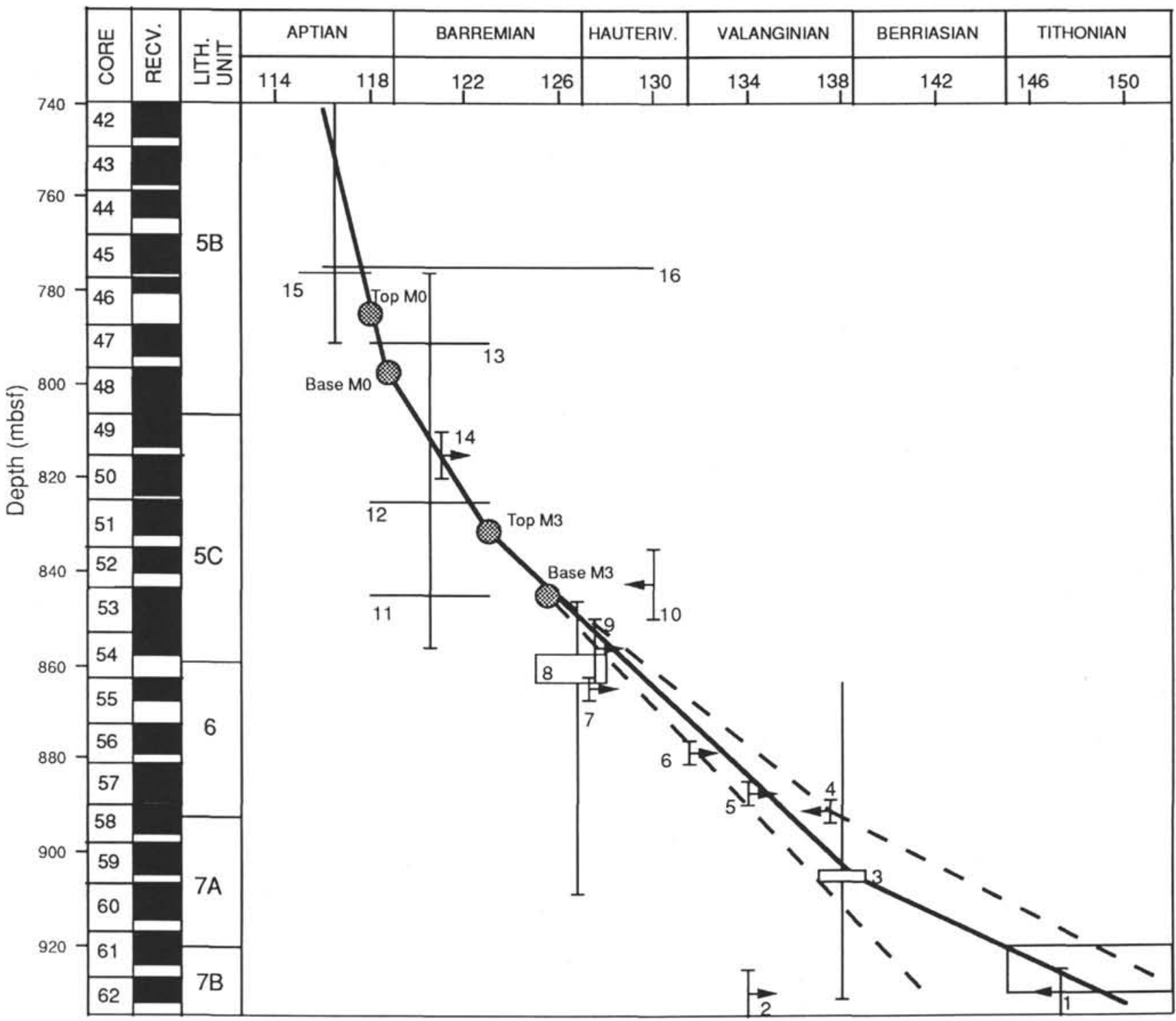

Figure 3. Age-depth model for the lower portion of Hole $765 \mathrm{C}$ (see Table 1).

Table 1. Biostratigraphic data from Hole 765C (see Fig. 3).

\begin{tabular}{|c|c|c|c|c|c|}
\hline & \multicolumn{2}{|c|}{ Biostratigraphic event } & \multirow{2}{*}{$\begin{array}{l}\text { Position in Hole } 765 \\
62 \mathrm{R}-1\end{array}$} & \multirow[t]{2}{*}{ Age } & \multirow{2}{*}{$\begin{array}{c}\text { Reference } \\
\text { Baumgartner (1984) }\end{array}$} \\
\hline 1 & $\mathbf{R}$ & FO H. barbui (=Zone D) & & & \\
\hline 2 & $\mathbf{R}$ & LO S. cetia & $62 R-1$ & late Valanginian & Schaaf (1985) \\
\hline 3 & $\mathbf{P}$ & E. torynum Zone & $59 \mathrm{R}-4$ \& 59R-5 & late Berriasian - early Valanginian & Helby et al. (1987) \\
\hline 4 & $\mathrm{~N}$ & FO Turbodiscus verenae & $58 \mathrm{R}-1,85 \mathrm{~cm}$ & earliest Valanginian & Bralower et al. (1989) \\
\hline 5 & $\mathbf{R}$ & LO $P$. amphitreptera & $57 \mathrm{R}-4$ & late Valanginian & Schaaf (1985) \\
\hline 6 & $\mathrm{~N}$ & LO Turbodiscus verenae & $56 \mathrm{R}-3,142 \mathrm{~cm}$ & late Valanginian & Bralower (1987) \\
\hline 7 & $\mathrm{~N}$ & occ. C. cuvillieri & $55 \mathrm{R}-1,41 \mathrm{~cm}$ & late Hauterivian or older & Bralower (1987) \\
\hline 8 & $\mathbf{P}$ & lower $M$. australis Zone & $54 \mathrm{R}-4$ and $54-\mathrm{CC}$ & late Hauterivian- early Barremian & Helby et al. (1987) \\
\hline 9 & $\mathbf{R}$ & LO S. leiostraca & $54 \mathrm{R}-4$ & late Hauterivian & Schaaf (1985) \\
\hline 10 & $\mathrm{R}$ & FO E. columbaria & $52 \mathrm{R}-2$ & late Hauterivian & Schaaf (1985) \\
\hline $11-13$ & P & upper $M$. australis Zone & $47 \mathrm{R}-1-52 \mathrm{R}-\mathrm{CC}$ & late Barremian & Helby et al. (1987) \\
\hline 14 & $\mathbf{R}$ & P. lilyae & $50 \mathrm{R}-1$ & mid late Barremian & Schaaf (1985) \\
\hline 15 & $\mathbf{P}$ & O. operculata Zone & $45 \mathrm{R}-\mathrm{CC}$ & early Aptian & Helby et al. (1987) \\
\hline 16 & $\mathrm{~F}$ & C. hoterivica & $45 \mathrm{R}-\mathrm{CC}$ & Barremian - early Aptian & DNAG time scale \\
\hline
\end{tabular}

Numbers refer to position of events on curve. $\mathrm{F}=$ foraminifer, $\mathrm{N}=$ nannofossil, $\mathrm{R}=$ radiolarian, $\mathrm{P}=$ palynomorph, $\mathrm{FO}=$ first occurrence, $\mathrm{LO}=$ last occurrence, occ. $=$ single occurrence. 
with similar assemblages slightly above basement in Hole 261 (Dumoulin and Bown, this volume). The age-depth curve for Hole 765C (Fig. 3, Table 1) has been revised accordingly and differs from the curve prepared for the "Site 765" chapter in the Leg 123 Initial Reports volume.

The lowermost $1.5 \mathrm{~m}$ of lithologic Unit VII, directly overlying oceanic basement, is barren of planktonic microfossils. Therefore, our estimate of a Tithonian age for the base of the sedimentary section in Hole $765 \mathrm{C}$ is based on linear extrapolation of the sediment accumulation-rate curve, assuming constant sedimentation rate, in accordance with standard ODP procedure. However, if the basal $1.5 \mathrm{~m}$ in Core $123-765 \mathrm{C}-62 \mathrm{R}$ represents a condensed interval, the age of the basal sediments might be somewhat older. Dumoulin and Bown (this volume) point out that the barren interval beneath the W. manivitae Zone in Hole 765C is thicker than a similar barren interval in Hole 261, which they consider is evidence for the base of Hole 765 being as old as, if not older than, the base of Hole 261.

\section{METHODS}

A total of 99 samples from lithologic Units V to VII in Hole $765 \mathrm{C}$ (Cores 123-765C-42R to -62R) was studied for foraminifers. The washed residues used to compile these data have been derived from three sources: (1) shipboard core-catcher samples plus several additional spot samples used for determining ages rapidly during Leg 123 , (2) 15 - to $20-\mathrm{cm}^{3}$ samples collected for shore-based foraminiferal studies, and (3) samples washed on board ship by Peter Baumgartner for analysis of radiolarians, which were later selected for benthic foraminifers.

All samples were boiled in a $1 \%$ Calgon solution and washed over a $63-\mu \mathrm{m}$ sieve. Samples processed on shore were dried overnight in a $60^{\circ}$ oven before washing. All foraminifers were chosen from the whole $>63-\mu \mathrm{m}$ fraction, according to standard micropaleontologic techniques. Specimens were mounted on cardboard reference slides, and specimens were illustrated using the scanning electron microscope. Plesiotypes are housed in MAK's collection at University College, London.

\section{RESULTS}

\section{Biostratigraphy}

The succession of benthic foraminiferal assemblages in Cores $123-765 C-42 R$ through $-62 R$ can be subdivided into five assemblages, based on species diversity and the stratigraphic occurrence of characteristic taxa (Figs. 4 and 5). The age assigned to each assemblage represents our best estimate from the age model for Hole 765C (Fig. 3, Table 1). The diversity of benthic foraminifers is greatest in upper Tithonian to Hauterivian sediments near the base of the sedimentary section and declines steadily up the section. In general, samples from red claystones contain diverse agglutinated assemblages; faunal data have been tabulated in Appendix A. Calcareous benthic foraminifers were found in four samples from calcareous turbidites, and these data are presented in Appendix B. Samples from turbidite layers and radiolarian sands higher in the section were barren of foraminifers, which is reflected in the plot of species diversity in Figure 4 (a complete list of barren samples is given in Appendix C). The assemblages of benthic foraminifers in Hole $765 \mathrm{C}$ are discussed next in order from oldest to youngest as follows:

1. Trochammina quinqueloba Assemblage

Sample 123-765C-62R-4, 25-27 cm to $-62 \mathrm{R}-1,53-56 \mathrm{~cm}$.

Age: (?)Tithonian.

The Trochammina quinqueloba Assemblage in Core 123$765 \mathrm{C}-62 \mathrm{R}$ is named after its most distinctive species, which is present in increased relative abundance, compared to the overlying assemblages, and is especially abundant at the base of the assemblage. The T. quinqueloba Assemblage represents an interval characterized by the absence of distinctive species that are present in the overlying assemblages. The age of this assemblage is constrained at the top of the interval by calcareous nannofossils belonging to an assemblage that is dominated by large $W$. manivitae, which according to Mutterlose (this volume) and Dumoulin and Bown (this volume) is Tithonian. However, the lowermost $1.5 \mathrm{~m}$ of Core $123-765 \mathrm{C}-62 \mathrm{R}$ remains undated as a result of the absence of planktonic microfossils. Therefore, the age of the base of the $T$. quinqueloba Assemblage cannot be determined directly. Using the accepted age model that assumes an average sedimentation rate (Fig. 3, Table 1), the extrapolated age of the base of the sedimentary section is about 150 m.y. (Tithonian). However, this estimate is subject to error.

Benthic foraminifers in the T. quinqueloba Assemblage are present in moderate diversity (7-17 species per sample) and are composed exclusively of agglutinated taxa. The dominant species are Glomospira charoides, Trochammina quinqueloba, Trochammina abrupta, and Psammosphaera sp. Three species are restricted to the assemblage: a coarsely agglutinated species of Ammobaculites (Plate 5, Figs. 1a and 1b), a distinctive, plano-convex species of Trochammina that bears some resemblance to Trochammina albertensis (Plate 6, Figs. 6a through 6c), and a species of Ammodiscoides (Plate 2, Fig. 1), which is common in Sample 123-765C-62R-4, 25-27 cm.

2. Pseudoreophax-Thalmannammina-Haplophragmoides kirki Assemblage

Samples $123-765 \mathrm{C}-61 \mathrm{R}-\mathrm{CC}$ to $-59 \mathrm{R}-5,78-80 \mathrm{~cm}$

Age: late Tithonian to late Berriasian.

The Pseudoreophax-Thalmannammina-Haplophragmoides kirki Assemblage in Cores $123-765 \mathrm{C}-61 \mathrm{R}$ to $-59 \mathrm{R}$ is named after three species that display last occurrences at the top of the interval. Two of these forms, Pseudoreophax cisovnicensis and Haplophragmoides kirki, are restricted to this interval. The age of the assemblage is constrained by nannofossils and radiolarians at its base, and by the presence of palynomorphs belonging to the latest Berriasian to early Valanginian E. torynum Zone of Helby et al. (1987). Interpolation from the sediment accumulation-rate curve (Fig. 3, Table 1) places the Berriasian/Valanginian boundary at about $900 \mathrm{~m}$.

The species diversity of benthic foraminifers in the Pseudoreophax-Thalmannammina-Haplophragmoides kirki Assemblage is the greatest observed in the studied interval of Hole $765 \mathrm{C}$, ranging from 21 to 32 species per sample. This assemblage is strongly dominated by agglutinated forms, with just one sample (123$765 \mathrm{C}-61 \mathrm{R}-5,58-60 \mathrm{~cm}$ ) containing few calcareous benthic forms that have probably been redeposited. The dominant forms throughout the interval are Glomospira charoides, Rhizammina spp., Ammodiscus tenuissimus, Trochammina abrupta, and Verneuilinoides neocomiensis. The base of the interval coincides with an abrupt increase in species diversity and the first occurrence of several species in Sample 123-765C-61R-CC, including Hormosina crassa, Pseudoreophax cisovnicensis, Haplophragmoides kirki, Verneuilinoides neocomiensis, Ammodiscus cretaceus, Glomospira irregularis, Glomospira sp. aff G. serpens, Praedorothia sp. B (Plate 7, Fig. 9), a five-chambered species of Haplophragmoides (Plate 4, Figs. 3 through 5), and a flat, coarse species of Ammodiscus having a wide whorl (Plate 2, Figs. 4 and 5). The first occurrence (FO) of Glomospirella, Subreophax, Spiroplectammina, Uvigerinammina, the species Reophax duplex, and another species of Praedorothia having a finely finished wall (Plate 6, Figs. 9 and 10) also occur within this assemblage. Many of these forms are typical components of Cretaceous cosmopolitan deep- 


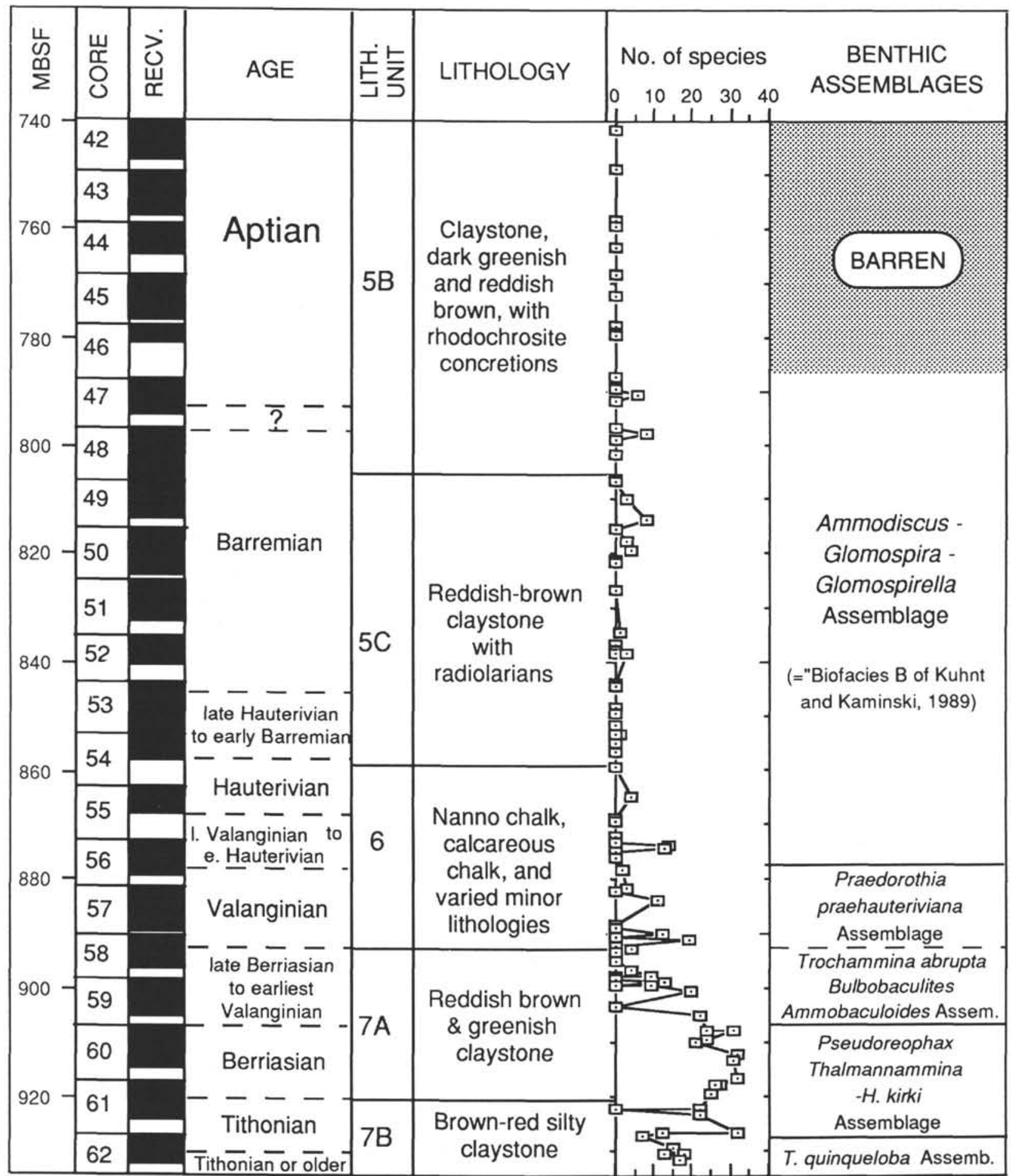

Figure 4. Chronostratigraphy, lithostratigraphy, and biostratigraphy of benthic foraminiferal assemblages in the lower portion of Hole $765 \mathrm{C}$. The top of the Tithonian has been placed at the highest occurrence of abundant, large W. manivitae, the base of the Valanginian has been placed at the FO of $T$. verenae, and the top of the Hauterivian coincides with the LOs of S. leiostracea and $C$. cuvillieri.

water agglutinated assemblages (e.g., Kuhnt and Kaminski, 1989).

The lower portion of the Pseudoreophax-ThalmannamminaHaplophragmoides kirki Assemblage can be further differentiated by the occurrence of Uvigerinammina (Plate 7, Figs. 10 through 13), a small, conical species of Marssonella (Plate 7, Fig. 8), and a species of Hormosina, which closely resembles the Upper Cre- taceous to lower Eocene species Hormosina excelsa (Dylazanka) (Plate 3, Figs. 2 and 3). The assemblages from Cores 123-765C$61 \mathrm{R}$ and $-62 \mathrm{R}$ also contain several species that apparently require the presence of coarse agglutinated particles or a suitable substrate for the construction of their test wall. The coarsely agglutinated species Psammosphaera fusca and a coarse species of Reophax are present in the lower portion of this interval, as well 


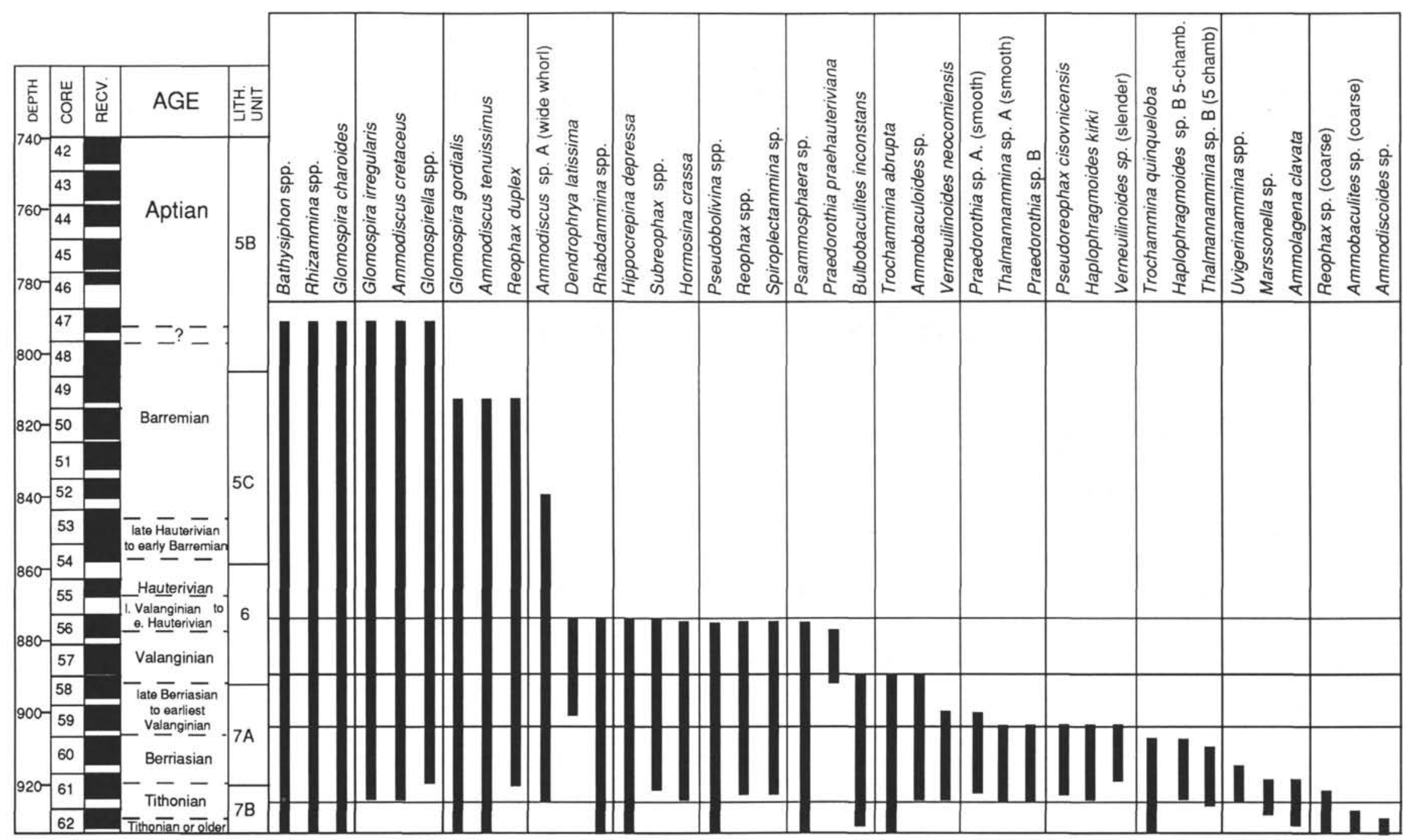

Figure 5. Stratigraphic ranges of common Lower Cretaceous agglutinated taxa in Hole 765C. 
as in the underlying assemblage. The adherent species Ammolagena clavata is uniquely dependent upon the presence of Inoceramus fragments, which it uses as substrate. This species is absent from pelagic substrates higher in the assemblage and has not been observed in Upper Cretaceous abyssal assemblages from pelagic substrates in the North Atlantic (Kuhnt and Kaminski, 1989).

3. Trochammina abrupta-Bulbobaculites inconstans-Ammobaculoides Assemblage

Samples $123-765 C-59 \mathrm{R}-2,121-125 \mathrm{~cm}$, to $-57 \mathrm{R}-\mathrm{CC}$.

Age: Valanginian.

The Trochammina abrupta-Bulbobaculites inconstans-Ammobaculoides Assemblage is named after three species that have last occurrences (LO) at the top of the interval. The sediments recovered in Cores 123-765C-58R and -59R (top of lithologic Unit VII) display an increase in the amount of biosiliceous sediments up the section, and the diversity and abundance of benthic foraminifers decreases concurrently. Of 14 samples examined from this interval, seven were barren of foraminifers. The diversity of agglutinated foraminifers, when present, varies between four and 20 species. The age of the top of the T. abrupta-B. inconstans-Ammobaculoides assemblage is well-constrained by the LO of the nannofossil Turbodiscus verenae in Sample 123-765C-58R-1, $85 \mathrm{~cm}$, and the LO of the radiolarian S. amphitreptera in Section 123-765C-57R-4, both of which indicate a late Valanginian age (Schaaf, 1985; Bralower et al., 1989). The age model for Hole $765 \mathrm{C}$ places the entire interval within the Valanginian.

The benthic foraminifers of the T. abrupta-B. inconstans-Ammobaculoides assemblage are numerically dominated by Rhizammina, G. charoides, Bathysiphon, and G. gordialis. Several species display LOs within the interval, including $V$. neocomiensis, Kalamopsis grzybowskii, and Praedorothia sp. B. A single sample (123-765C-58R-2, 10-14 cm) contains few specimens of calcareous benthic foraminifers, including a slightly nodose form of Lenticulina, which may belong to the Lower Cretaceous index species Lenticulina nodosa.

4. Praedorothia praehauteriviana Assemblage

Samples $123-765 \mathrm{C}-57 \mathrm{R}-6,57-59 \mathrm{~cm}$, to $-56 \mathrm{R}-1,134-136 \mathrm{~cm}$.

Age: upper Valanginian.

This assemblage is named after the common occurrence of Praedorothia praehauteriviana in Samples 123-765C-56R-4, $144-146 \mathrm{~cm}$, and $-56 \mathrm{R}-\mathrm{CC}$. The base of the assemblage coincides approximately with the base of lithologic Unit VI, which is characterized by the presence of minor calcareous facies. The LO of the nannofossil Turbodiscus verenae in Sample 123-765C$56 \mathrm{R}-3,142 \mathrm{~cm}$, constrains the age of this interval as upper Valanginian, according to Bralower (1987).

With the exception of the two calcareous samples, species diversity is low and ranges from 2 to 14 species of agglutinates, dominated by Rhizammina, Rhabdammina, and Glomospira. The two calcareous samples have been derived from calcareous turbidites and contain at least 20 species of calcareous benthic foraminifers (Appendix B). Seven of the 13 samples examined from this interval are barren of foraminifers. The top of the $P$. praehauteriviana Assemblage is delineated by the LO of all remaining "flysch-type" agglutinated forms, such as Dendrophrya, Rhabdammina, Hippocrepina, Reophax, Subreophax, Hormosina, Pseudobolivina, Spiroplectammina, and Praedorothia.

5. Ammodiscus-Glomospira-Glomospirella Assemblage Samples $123-765 C-56 \mathrm{R}-1,110-114 \mathrm{~cm}$, to $-47 \mathrm{R}-3,9-13 \mathrm{~cm}$.

Age: Hauterivian to earliest Aptian.
This sparse assemblage of agglutinated foraminifers is named after the three most characteristic genera occurring in the interval. Only 10 of the 51 samples examined from Cores $123-765-42 R$ to $-55 R$ contain foraminifers. Species diversity of benthic foraminifers, when present, is the lowest observed in the studied section, ranging from one to eight species. The top of the assemblage is contained within an interval of reversely magnetized sediments that correspond to marine magnetic anomaly M0, which correlates to the basal Aptian. The species found in this assemblage include Bathysiphon sp., Rhizammina sp., Glomospira charoides, G. irregularis, $G$. gordialis, $G$. aff. G. serpens, $G$. sp. aff. $G$. diffundens, Glomospirella gaultina, Ammodiscus cretaceus, and A. tenuissimus. All samples examined from Cores $123-765 \mathrm{C}-42 \mathrm{R}$ to $-46 R$ were barren of foraminifers.

\section{DEPOSITIONAL ENVIRONMENT}

According to the plate-tectonic scenario proposed by AudleyCharles et al. (1988) and Fullerton et al. (1989), the Argo Abyssal Plain at Site 765 formed during the Late Jurassic (164 Ma), when seafloor spreading transported a long continental block (southern Tibet and Burma) away from northwestern Australia. The initial opening of the Argo Basin was diachronous, propagating from west to east. Assuming that this scenario is correct, a hiatus or an extremely condensed horizon accounting for $15 \mathrm{~m}$.y of nondeposition separates the base of the dated sedimentary section in Hole $765 \mathrm{C}$ from oceanic basement. Why sediments bypassed Site 765 for the first 15 m.y. of its history is not clear, because the site is situated on a basement low. In any case, the oldest dated (Tithonian) sediments at Site 765 were deposited in a quiet, abyssal environment beneath the CCD, analogous to that of the Kimmeridgian to Lower Cretaceous sediments at DSDP Site 261, located $250 \mathrm{~km}$ to the north. Thermal subsidence calculations for normal oceanic crust (Sclater et al., 1985) indicate that the depth of the ridge crest when the ocean crust was formed was approximately $2.7 \mathrm{~km}$. Site 765 subsided to a depth of about $4.7 \mathrm{~km}$ by the late Barremian. Benthic foraminiferal assemblages from Hole 765C thus are truly abyssal in character and contain many cosmopolitan species, indicating free deep-water connections with the Tethys Ocean to the north.

The deposition of lithologic Subunit VIIB was influenced to a large extent by distal turbidites, and the sand fraction of the sediment is dominated by Inoceramus fragments with minor amounts of detrital quartz and biosiliceous particles. The clastic nature of the samples from lithologic Subunit VIIB is reflected in the composition of the benthic foraminiferal assemblage. For example, the species Ammolagena clavata, which is practically unknown from Upper Cretaceous pelagic substrates (Kuhnt and Kaminski, 1989), is common in the lower portion of Subunit VIIB, where it uses Inoceramus fragments as a substrate. Coarsely agglutinated forms, such as Ammobaculites sp. and Reophax sp. $\mathrm{C}$, are restricted to this interval. The diversity of DWAF is lower in this clastic interval than in the overlying hemipelagic claystones. This observation is consistent with previous studies of Upper Cretaceous and Paleogene flysch-type agglutinated assemblages (Kaminski et al., 1988), which documented lower diversity within turbidite layers.

The influence of terrigenous sedimentation declines up the section from lithologic Subunits VIIB to VIIA, which is composed largely of smectite-rich hemipelagic claystones with only minor turbidite components. The sand fraction from Cores 123$765 \mathrm{C}-58 \mathrm{R}$ to $-60 \mathrm{R}$ consists largely of agglutinated foraminifers, with only minor amounts of zeolite crystals and radiolarians, attesting to a greatly lessened contribution by distal turbidites. The DWAF assemblages in these claystones display their maximum development in terms of abundance and diversity. The 
assemblage from this interval includes several forms that have not been previously reported from abyssal sediments of this age, such as the species Ammolagena clavata, Reophax duplex, Haplophragmoides kirki, Trochammina abrupta, Hormosina excelsa, and undetermined species of Trochamminoides, Paratrochamminoides, and Thalmannammina (see also reviews by Riegraf and Luterbacher, 1989a, 1989b). These forms are typical of Upper Cretaceous DWAF assemblages, and their presence at Site 765 indicates that they have a longer geologic record than was previously assumed.

The Valanginian to Hauterivian interval represented by lithologic Unit VI shows an increase in the contribution of distal turbidites, and more importantly for the benthic assemblages, an increase in calcareous and biosiliceous sedimentation. The lithologies sampled for benthic foraminifers included an assortment of red silty claystones and gray or greenish-gray laminated sandy layers. Most of the turbidite layers sampled consist exclusively of size-sorted, well-preserved radiolarians and are barren of foraminifers. Radiolarian assemblages from these layers differ taxonomically from those of the hemipelagic red claystones (P. O. Baumgartner, pers. comm. to MAK, 1988), indicating a different source region, possibly the outer Exmouth Plateau.

Two samples in particular (123-765C-56R-4, 144-148 cm, and $-56 \mathrm{R}-\mathrm{CC}$ ) were derived from calcareous turbidites and contain a mixture of agglutinated and redeposited calcareous species. The upper sample was a size-graded gray sand, and the washed residue consists largely of amorphous calcareous particles. The foraminiferal assemblage is composed mostly of calcareous forms, dominated by nodosariids (Lenticulina spp., Nodosaria spp., Vaginulopsis spp.), polymorphinids, and the calcareous agglutinated species Praedorothia praehauteriviana. These forms are characteristic of Neocomian deep-water assemblages reported from DSDP Site 416 in the eastern North Atlantic (Sliter, 1980) and from Sites 391 and 534 in the western North Atlantic (Gradstein, 1983). Shallow-water forms, such as miliolids, epistominids, and frondiculariids, are notably absent, indicating a relatively deep source area. Sample 123-765C-56R-CC also consists of a turbidite layer, but the sand fraction in this case consists of Inoceramus prisms and detrital quartz. Although the benthic foraminiferal assemblage is still dominated by the forms listed above, the assemblage also contains a few specimens of Frondicularia, Epistomina, and Paalzowella. The presence of these forms, along with that of detrital quartz, suggests redeposition from a shallower, more-clastic source area. The presence of minor calcareous lithologies in Unit VI may indicate deposition at or just below the CCD, as suggested by von Rad et al. (1989). However, in comparison to the sedimentary record from DSDP Site 534 (which was at a slightly deeper paleodepth than Site 765), the CCD in the Argo Abyssal Plain must have remained higher than in the Atlantic throughout the Early Cretaceous.

Within lithologic Unit VI, the occurrence of radiolarites and redeposited radiolarian sands increases up the core into lithologic Subunit VC. The abundance and diversity of benthic foraminifers decline over the same interval. The LO of typical flysch-type benthic foraminifers was observed in Core 123-765C-56R. Above this level, the benthic foraminifer assemblage is wholly composed of agglutinated species that are dominated by Rhizammina and ammodiscids (Ammodiscus, Glomospira, and Glomospirella). This type of agglutinated assemblage (characterized by ammodiscids) displays a remarkably consistent occurrence in Upper Cretaceous biosiliceous sediments and corresponds to the "Biofacies B" assemblage of Kuhnt et al. (1989) and Kuhnt and Kaminski (1989). This Biofacies B assemblage is taxonomically distinct, and because it consists mainly of stratigraphically long-ranging forms is a recurring feature of Cretaceous and Paleogene DWAF assemblages. Interestingly, this biofacies is often associated with biosiliceous, radiolarian-rich sediments. In the North Atlantic, Biofacies B assemblages have been observed in greenish to dark gray, carbonate-free deep-sea clays that directly overlie the benthic-free black shale at the Cenomanian/Turonian boundary in DSDP Hole 641A (Core 641A-6X), and in the lower Turonian and lower Campanian of DSDP Hole 603B (Kuhnt et al., 1989). In DSDP Hole 543A, such assemblages also occur in Core 543A-5R, directly underlying biosiliceous sediments of the $B$. bidartensis Zone (latest Paleocene-earliest Eocene). In the western Mediterranean, we recognize foraminiferal assemblages similar to Biofacies B in the Turonian of the Gubbio section, especially in samples collected near cherts. The grayish or greenish-gray claystones can show increased TOC-values, indicating somewhat oxygen-depleted bottom and interstitial waters.

The foraminiferal content of these biosiliceous sediments consists of impoverished agglutinated assemblages that are generally composed of compressed specimens showing a whitish agglutinating wall. The Upper Cretaceous assemblages have high abundances of thin-walled, fine-grained, often compressed forms, such as Ammodiscus spp., Glomospirella gaultina, Glomospira gordialis, G. charoides, thin-walled Glomospira serpens, elongate specimens of the genus Pseudobolivina, and tube-shaped forms that can be assigned to the genus Rhizammina. In addition, Uvigerinammina, Hormosina, Haplophragmoides concavus, Thalmannammina spp., Karreriella, and Paratrochamminoides may occur. Our finding of a Biofacies B assemblage in the Hauterivian to Barremian of Hole $765 \mathrm{C}$ indicates that this type of assemblage is a conservative and characteristic feature of areas having high biosiliceous productivity, from at least the Early Cretaceous to the Eocene.

\section{FAUNAL COMPARISONS}

Upper Jurassic to Lower Cretaceous deep-water benthic foraminifers have now been studied from eight DSDP sites in the North Atlantic (Luterbacher, 1972; Maync, 1973; Kuznetsova and Siebold, 1977; Sliter, 1980; Gradstein, 1983) and from Site 261 in the Argo Abyssal Plain (Kuznetsova, 1974; Bartenstein, 1974; Riegraf and Luterbacher, 1989a, 1989b). For this comparison, we have reexamined samples from DSDP Site 534 to clarify any taxonomic uncertainties. In addition to compiling the published data from these sites, we present published and unpublished data from two localities in the mountain chains of central Europe and Asia to provide a comparison with coeval bathyal biofacies from the Tethyan margins (Fig. 6):

1. The preliminary results from Leg 123 encouraged one of us (S.G.) to undertake a detailed stratigraphic and taxonomic study of the agglutinated foraminifers from the Tithonian to Berriasian flysch deposits of the Polish Carpathians. The so-called "Cieszyn Limestones" were deposited on the northern margin of the Tethys seaway and constitute the oldest deep-water facies in the Carpathian troughs. Details of this study will be published separately (Geroch and Olszewska, 1990).

2. We also examined benthic foraminifers in samples that two of us (MAK and FMG) collected from the upper Oxfordian to upper Tithonian Nupra Formation in the Thak Khola region of central Nepal. The Nupra Formation consists of dense, black shale that was deposited in an outer neritic to upper bathyal oxygenminimum zone on the northern margin of the Indian Plate. Stratigraphic and geochemical results of a recent study of the Nupra Shale were reported by Gradstein et al. (1989). A comparison of the stratigraphic ranges of selected cosmopolitan agglutinated species from Hole $765 \mathrm{C}$ with their reported ranges in Atlantic 


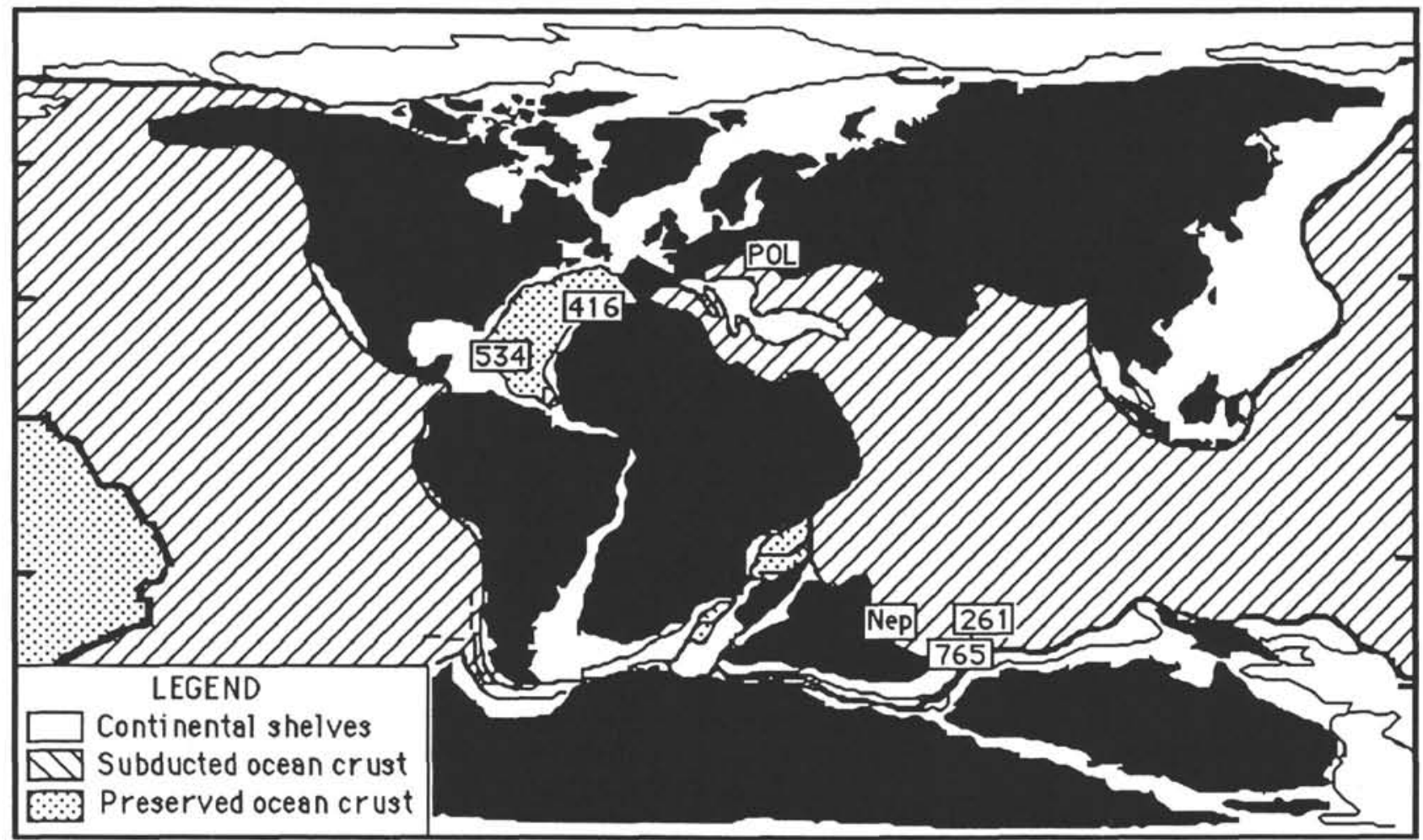

Figure 6. Berriasian paleogeography based on the plate tectonic reconstruction of Barron (1987), and localities for Lower Cretaceous deep-water benthic foraminifers.

DSDP holes, the Carpathians, central Nepal, and at DSDP Site 261 is presented in Figure 7.

\section{Site 261}

Benthic foraminiferal assemblages from the Uppermost Jurassic to Lowermost Cretaceous sediments recovered at Site 261 are those most directly comparable with the assemblages from Hole $765 \mathrm{C}$. Site 261 was drilled on crust of late Oxfordian age approximately $250 \mathrm{~km}$ north of Site 765 . The simple (single-chambered) agglutinates from Cores 261-25R to -33R directly above basement were studied by Bartenstein (1974), and the complex (multilocular) agglutinates and calcareous benthic species from Cores 261$29 \mathrm{R}$ to $261-35 \mathrm{R}$ were described by Kuznetsova (1974). Kuznetsova regarded the assemblages from the base of Hole 261 (Cores 261-32R to 261-35R) as a mixture of reworked Upper Jurassic (Callovian to Oxfordian) and Lower Cretaceous ("not older than Valanginian") species, based on the absence of typical Upper Jurassic forms, such as ophthalmidiids, ceratobuliminids, and trocholinids. However, these forms are typical of shallowwater facies; thus, their absence from Hole 261 is not surprising. She regarded the assemblages from higher in the section (Cores 261-30R and 261-31R) as Valanginian on the basis of the occurrence of Bulbobaculites inconstans, Verneuilinoides neocomiensis, and Praedorothia. The chronostratigraphy of Hole 261 presented by Riegraf and Luterbacher (1989a) essentially follows that of Kuznetsova. However, our reevaluation of Kuznetsova's data, based on comparisons with the Polish Carpathians and Atlantic DSDP sites, together with the available nannofossil data from Site 261 (Proto-Decima, 1974, and Dumoulin and Bown, this volume), is consistent with a Late Jurassic to Early Cretaceous age for the section. The nannofossil data from Hole 261 yield a linear age model (Fig. 8, Table 2), and when benthic foraminiferal events are added to the model for comparison, the agreement with their known stratigraphic ranges at other localities (e.g., Gradstein, 1983; Geroch and Olszewska, 1990) is surprisingly good. From Hole 261, scientists recovered somewhat older sediments than those that we dated in Hole $765 \mathrm{C}$, which provides evidence for lower Tithonian or older ranges of these benthic foraminifers (the nannofossil marker for the lower Tithonian, S. bigotii, was found at Site 261 but not at Site 765). With this revised age model for Site 261, benthic foraminiferal events can be compared directly with those present in Hole 765C (Fig. 7).

In comparison to Hole $765 \mathrm{C}$, the upper ranges of DWAF assemblages in Hole 261 appear to be truncated in the upper Berriasian or lower Valanginian. Kuznetsova reported a change from a diversified, agglutinated, and calcareous benthic assemblage (below) to an assemblage dominated by Glomospira charoides, G. gordialis, and Glomospirella gaultina (above) within Core 261-30R. Benthic assemblages from overlying Cores 26127R through 261-9R are characterized by "very poor arenaceous foraminifera [...] with Ammodiscus sp., Glomospira sp., Bathysiphon sp., and Hyperammina sp." (Kuznetsova, 1974, p. 138). This assemblage is found in association with "poorly preserved radiolarians" (op. cit.), and is directly comparable to our "Biofacies B" assemblage in Cores $123-765 \mathrm{C}-42 \mathrm{R}$ to $-56 \mathrm{R}$. The base of this interval has been estimated as $132 \pm 0.5 \mathrm{Ma}$ from our age model for Hole 765C (Fig. 3, Table 1). If this age for the base of "Biofacies B" is correct, and this value is used for the base of "Biofacies B" in Hole 261 (point in Fig. 8, Table 2), the onset of "Biofacies B" is observed to be diachronous by about 6 m.y. between the two sites. This biofacies first appeared within the early Valanginian at Site 261, but did not appear until the latest Valanginian or early Hauterivian at Site 765 . This suggests that "Biofacies B" is intimately dependent upon the local sedimentary environment, such as the depth of the site in relation to the CCD and the presence of upwelling or nutrient influx that results in biosiliceous sedimentation. 


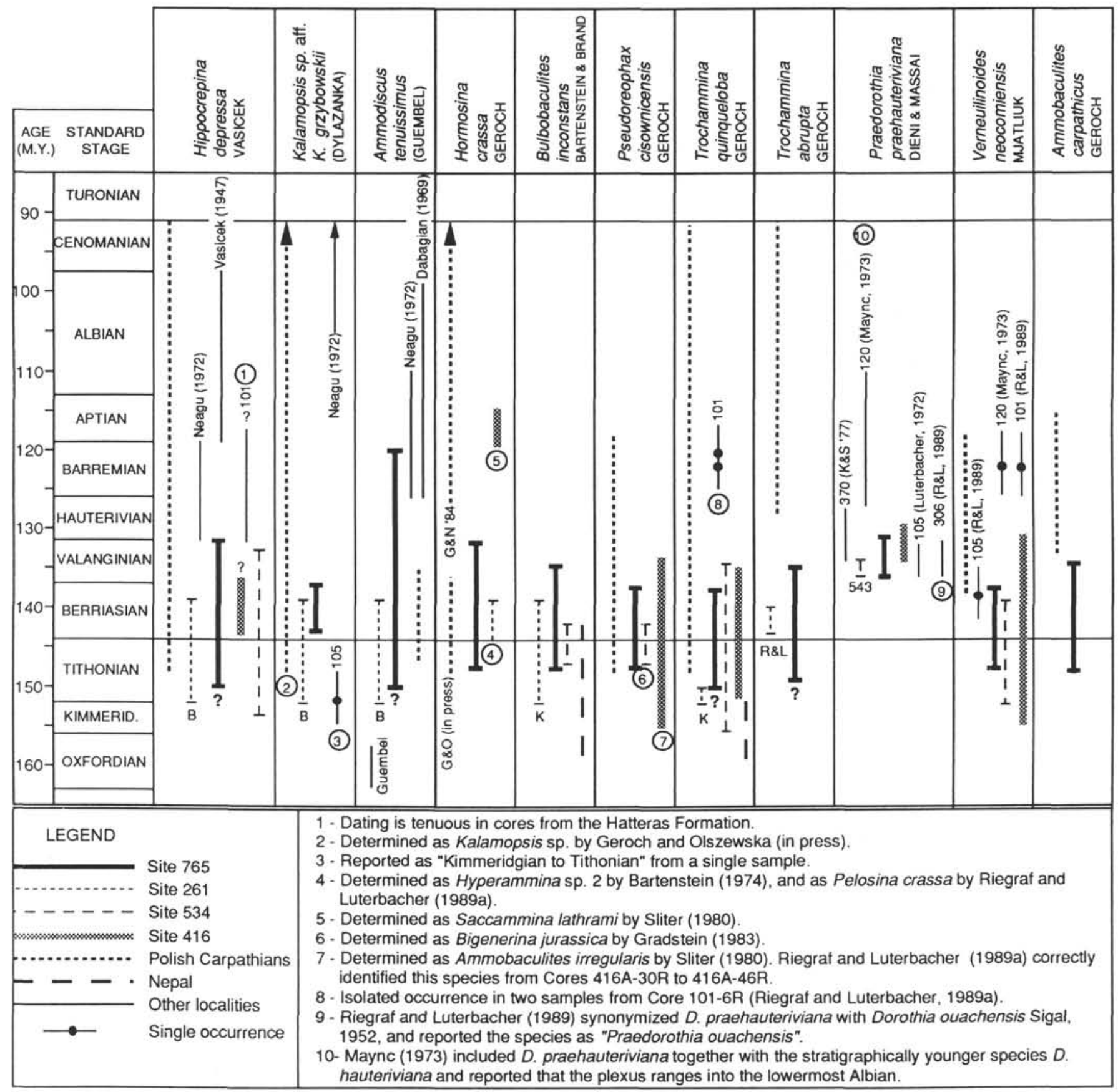

Figure 7. Stratigraphic ranges of selected cosmopolitan Upper Jurassic to Lower Cretaceous DWAF from Site 765, compared with their reported ranges at other localities. Foraminiferal data from Site 261 were compiled from Bartenstein (1974), Kusnetsova (1974), and Riegraf and Luterbacher (1989a) and are marked with a "B," "K," or "R\&L," depending on the source of the data. The chronostratigraphy of the Hole 261 is according to our reinterpretation of nannofossil and foraminiferal data (Fig. 8). time scale. Biostratigraphic data in DSDP Holes 101 and 105 are from Luterbacher (1972) and Riegraf and Luterbacher (1989a); Hole 120 data are from Maync (1973); Hole 370 from Kuznetsova and Siebold (1977); Hole 543A from Gradstein (1983), supplemented by additional observations. Stratigraphic ranges in the Carpathian flysch troughs were compiled from Dabagian (1969), Neagu (1972), Vasicek (1947), Geroch and Nowak (1984), and Geroch and Olszewska (in press). Data from the Nupra Shales of central Nepal are unpublished data based on the work of Gradstein et al. (1989).

\section{North Atlantic}

We compiled benthic foraminiferal data from the Upper Jurassic to Neocomian Cat Gap and Blake-Bahama formations at Sites $100,101,105$, and 534 in the western North Atlantic, and from Sites 120, 367, 370, and 416 in the eastern North Atlantic. In general, sediments from the western North Atlantic are richer in carbonate and contain more radiolarian-bearing horizons than sediments from the eastern North Atlantic.

Hole 534A offers the most complete stratigraphic record spanning the Jurassic/Cretaceous boundary, and benthic foraminifers from the site were first studied by Gradstein (1983). Overall, 


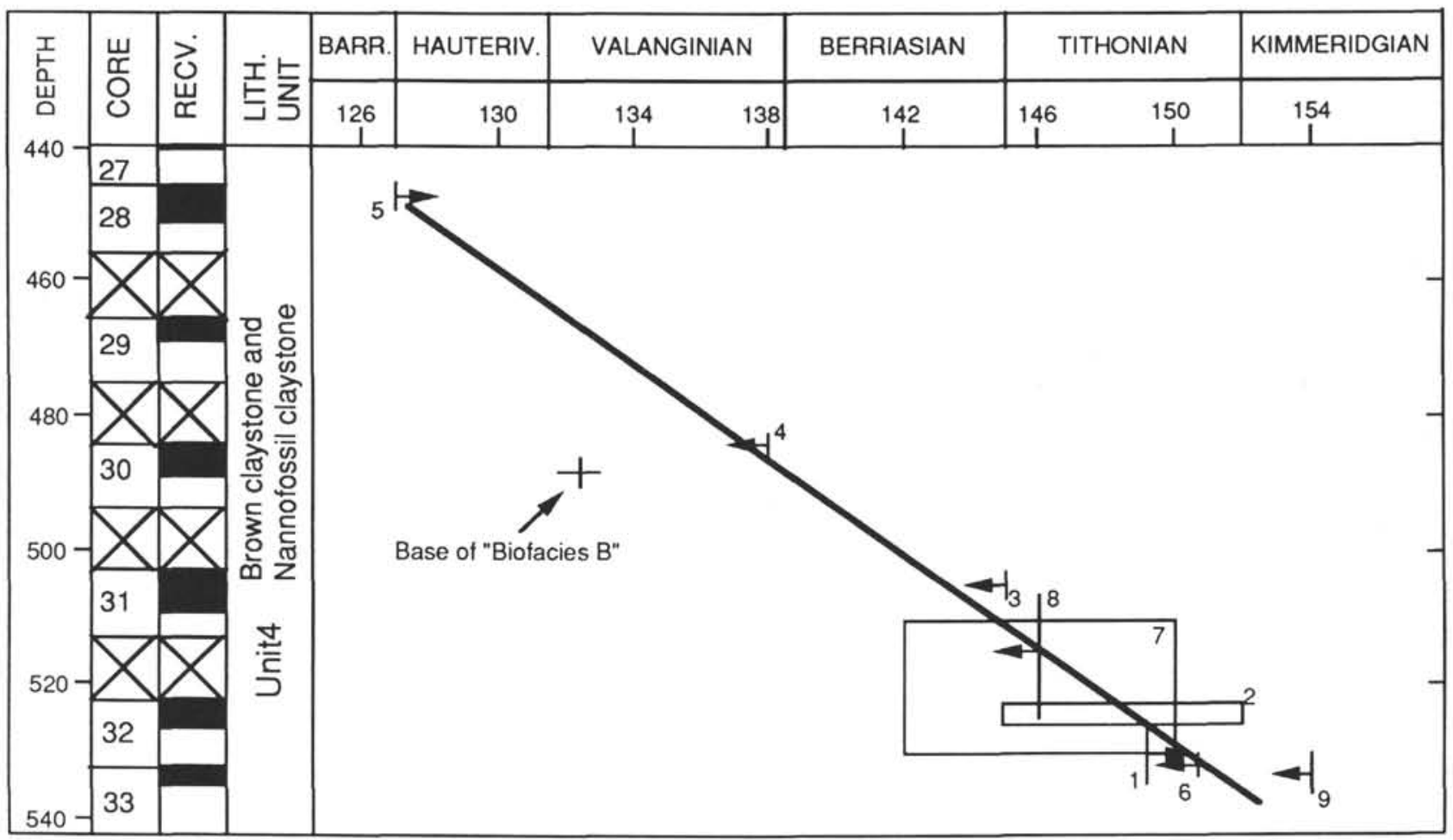

Figure 8. Age-depth model for the Upper Jurassic to Lower Cretaceous of Site 261 (see Table 2).

Table 2. Biostratigraphic data from Site 261 (see Fig. 8).

\begin{tabular}{|c|c|c|c|c|c|}
\hline & & Biostratigraphic event & Position in Hole 261 & Age & Reference \\
\hline 1 & $\mathrm{~N}$ & LO Stephanolithon bigotii & $33 \mathrm{R}-1,10 \mathrm{~cm}$ & early Tithonian & Bown et al. (1988) \\
\hline 2 & $\mathrm{~N}$ & occ. abundant $W$. manivitae & $32 \mathrm{R}-2,70 \mathrm{~cm}-30 \mathrm{R}-\mathrm{CC}$ & Tithonian & Bown (this volume) \\
\hline 3 & $\mathrm{~N}$ & FO Cruciellipsis cuvillieri & $31 \mathrm{R}-2,122 \mathrm{~cm}$ & uppermost Tithonian & Bralower et al. (1989) \\
\hline 4 & $\mathrm{~N}$ & FO Turbodiscus verenae & $30 \mathrm{R}-2,60 \mathrm{~cm}$ & lowermost Valanginian & Bralower et al. (1989) \\
\hline 5 & $\mathrm{~N}$ & occ. C. cuvillieri & $28 \mathrm{R}-1,70 \mathrm{~cm}$ & late Hauterivian or older & Bralower (1987) \\
\hline 6 & B & FFO $V$. neocomiensis & $35 \mathrm{R}-5,120 \mathrm{~cm}$ & early Tithonian & Gradstein (1983) \\
\hline 7 & BF & B. inconstans & $32 R-3-31 R-C C$ & early Tithon - early Berriasian & Gradstein (1983) \\
\hline 8 & $\mathrm{BF}$ & FO $H$. ovulum group & $31 \mathrm{R}-\mathrm{CC}$ & Clate Tithonian & Geroch and Olszewska (1990) \\
\hline 9 & $\mathrm{BF}$ & Hippocrepina depressa & $32 \mathrm{R}-\mathrm{CC}$ & Clate Kimmeridgian & Gradstein (1983) \\
\hline
\end{tabular}

Numbers refer to position of events on curve. $\mathrm{N}=$ nannofossil, $\mathrm{BF}=$ benthic foraminifer, $\mathrm{FO}=$ first occurrence, $\mathrm{LO}=$ last occurrence, occ. $=$ single occurrence.

faunal communality between the benthic assemblages at Sites 534 and 765 is low, because most of the typical "flysch-type" agglutinated elements are missing at Site 534. About 20 forms are in common between the two localities, and most of these are the ubiquitous cosmopolitan forms, such as Rhizammina spp., Bathysiphon sp., Hyperammina sp., Psammosphaera sp., Saccammina sp., Glomospira charoides, G. gordialis, Glomospira irregularis, Glomospirella gaultina, Ammodiscus cretaceus, Subreophax sp., and Lituotuba sp. However, a number of potentially useful forms are present, including Hippocrepina depressa, Bulbobaculites inconstans, Pseudoreophax cisovnicensis (illustrated as Bigenerina jurassica by Gradstein, 1983), Trochammina quinqueloba, Praedorothia praehauteriviana, and Verneuilinoides neocomiensis (Fig. 7).

Of the species mentioned above, Praedorothia praehauteriviana displays the most tightly defined and consistent stratigraphic distribution. The $P$. praehauteriviana Assemblage from Hole $765 \mathrm{C}$ is the temporal equivalent of similar $P$. praehauteriviana assemblages from Holes 534A, 416A, 370, 105, and 101. Only the published record of this species from Hole 120 diverges from its typical Valanginian to lower Hauterivian range. How- ever, this is because Maync (1973) lumped this species together with the stratigraphically younger species Praedorothia hauteriviana (Moullade).

Gradstein (1983) suggested the possibility of making miscellaneous stratigraphic correlations between Sites 534 and 261 using the species Trochammina quinqueloba and Bulbobaculites inconstans. Both of these forms also were found to occur in sediments as old as upper Oxfordian in the Nupra Formation of central Nepal (Fig. 7), which revises downward their known stratigraphic range. Unfortunately, sediments of equivalent age were not recovered from the Argo Abyssal Plain. In the case of several noncalcareous agglutinated taxa (Hippocrepina depressa, $B$. inconstans, Pseudoreophax, and $V$. neocomiensis), a familiar pattern emerges. These species, which predominantly occur in Tithonian to Berriasian strata in the Atlantic, range into younger stratigraphic horizons at Site 765. This pattern of truncated ranges at Site 534 can be attributed to differences between the sedimentary environments of the two ocean basins. Sediments in the western North Atlantic become increasingly more calcareous from the Tithonian sequence to the Berriasian sequence. In addition, beginning with the Berriasian, radiolarians are consistently 
present in the washed residues from Hole 534A. As a result of increased calcareous and biosiliceous sedimentation, DWAF become rare and scattered above $1350 \mathrm{mbsf}$ in Hole 534A. One notable exception to this pattern is the stratigraphic range of $T$. quinqueloba. At Site 765, the LO of T. quinqueloba occurs below the FO of $P$. praehauteriviana, whereas at Site 534, the ranges of the two species overlap, and $T$. quinqueloba ranges into the lower Valanginian. Above the Hauterivian, the record of DWAF assemblages from all the studied Atlantic and Indian Ocean abyssal sites is poor, and the species have often been reported only from single samples. In the bathyal flysch sequences of the Carpathian troughs, however, most of these forms persist into younger stratigraphic levels.

\section{Carpathians}

Bathyal DWAF assemblages from the northern margin of the Tethys are preserved in the flysch sequences of the Carpathians from Poland to Romania. Many of the cosmopolitan species from Hole $765 \mathrm{C}$ were first described from the Lower Cretaceous flysch deposits in the Polish Carpathians, so it is instructive to compare the biostratigraphic record of the two regions.

The oldest deep-water deposits of the outer flysch Carpathians in Poland are the so-called "Cieszyn Limestones," which have been dated as upper Tithonian to Berriasian on the basis of aptychi, calpionellids, and stomiosphaerids (Gasiorowski, 1962; Nowak, 1968). The Cieszyn Limestones represent a calcareous flysch facies that is composed of well-bedded detritic and pelitic limestones, with interbedded marls and marly shales, which have been interpreted as hemipelagic sediments (Slomka, 1986). Geroch and Olszewska (1990) examined more than 100 samples from the marly shale interbeds. Agglutinated foraminifers from the unit are dominated by tubular forms, but others can be found, such as Pseudoreophax cisownicensis, which constitutes up to $20 \%$ of the assemblage, Trochammina quinqueloba (up to $10 \%$ ) and rare Kalamopsis. A total of 20 species belonging to 15 genera have been found in addition to these forms, including Hyperammina sp., Saccammina sp., Psammosphaera sp., H. depressa, Ammodiscus cretaceus, A. tenuissimus, G. charoides, G. gordialis, G. gaultina, Hormosina sp., Reophax sp., Gaudryina sp., and Verneuilinoides sp. The detailed study of these Tithonian to Berriasian assemblages enables us to extend downward several of the stratigraphic ranges of DWAF previously reported by Geroch and Nowak (1984).

In nearly all cases, the stratigraphic ranges of species at Site 765 overlap with their reported ranges in the bathyal flysch sequences of the Carpathians. However, two examples of disjunct stratigraphic ranges are provided by Trochammina abrupta and the genus Ammobaculoides. These forms were present at Site 765 during the Tithonian to Valanginian, but did not appear in the Carpathian troughs until later. This pattern may be due to differences in paleobathymetry (bathyal vs. abyssal), or it may imply the presence of a selective faunal barrier between the northern and southern margins of the Tethys. However, neither of these two species has been previously reported from DSDP/ODP sites, and more observations will be necessary to determine their paleoecology.

\section{SUMMARY}

In the intervening years since the Glomar Challenger was used to recover the first abyssal DWAF assemblages from Site 261, many advances have come about in the study of Upper Jurassic and Lower Cretaceous deep-water foraminiferal taxonomy and biostratigraphy. However, Kusnetsova's statement about the unique composition of assemblages from the Argo Abyssal Plain still holds true to some extent. Assemblages from Hole $765 \mathrm{C}$ are the taxonomically most diverse agglutinated assemblages yet recovered from abyssal Uppermost Jurassic to Lower Cretaceous sediments. Despite their "uniqueness," it is apparent that the DWAF assemblages from Hole 765C consist to a large extent of cosmopolitan species that, presumably, readily thrived in the sub-CCD environment. Our refined and integrated biostratigraphic record from Hole $765 \mathrm{C}$ should be valuable for helping to constrain evolutionary and paleobiogeographic patterns in deepwater benthic foraminifers and may provide a framework for future studies of the Mesozoic abyssal environment.

\section{ACKNOWLEDGMENTS}

MAK gratefully acknowledges the Ocean Drilling Program for the opportunity to participate in Leg 123 and for providing samples, as well as the assistance of Leg 123 micropaleontologists Peter Baumgartner, Paul Bown, Andy McMinn, and Jorg Mutterlose for contributing unpublished data used to construct age models for Holes 261 and $765 \mathrm{C}$. We thank Danuta Kaminski for help with sample preparation. Theodor Neagu offered many useful suggestions for the taxonomy of Lower Cretaceous agglutinated foraminifers. Frank Thomas (Geological Survey of Canada) assisted with the photography. We thank Bill Berggren (WHOI) and Drew Haman (Chevron, USA) for their helpful comments about the manuscript. MAK was supported by a post-doctoral fellowship from the Natural Science and Engineering Research Council of Canada and contracts from the Geological Survey of Canada. Travel support to participate in Leg 123 was provided by an NSERC Strategic Grant to Ron Boyd (Dalhousie University). This is Contribution No. 27 of the Deep-Water Agglutinated Foraminifera Project.

\section{REFERENCES}

Audley-Charles, M. G., Ballantyne, P. D., and Hall, R., 1988. Mesozoic-Cenozoic rift-drift sequence of Asian fragments from Gondwanaland. Tectonophysics, 155:317-330.

Barron, E. J., 1987. Cretaceous plate tectonic reconstructions. Paleogeog., Paleoclimatol., Paleoecol., 59:3-29.

Bartenstein, H., 1974. Upper Jurassic-Lower Cretaceous primitive arenaceous foraminifera from DSDP Sites 259 and 261, Eastern Indian Ocean. In Veevers, J. J., Heirtzler, J. R., et al., Init. Repts. DSDP, 27: Washington (U.S. Govt. Printing Office), 683-695.

Baumgartner, P. O., 1984. A Middle Jurassic-Early Cretaceous low latitude radiolarian zonation based on unitary associations and age of Tethyan radiolarites. Eclogae Geol. Helv., 77:729-837.

Berthelin, G., 1880. Memoire sur les foraminiferes fossiles de l'étage Albien de Montcley (Doubs). Mem. Soc. Geol. France, Ser. 3, 1:1-84.

Bown, P. R., Cooper, M.K.E., and Lord, A. R., 1988. A calcareous nannofossil biozonation scheme for the early to mid Mesozoic. Newsl. Stratigr., 20:91-114.

Bralower, T. J., 1987. Valanginian to Aptian calcareous nannofossil stratigraphy and correlation with the upper M-sequence magnetic anomalies. Mar. Micropaleontol., 11:293-310.

Bralower, T. J., Monechi, S., and Thierstein, H. R., 1989. Calcareous nannofossil zonation of the Jurassic/Cretaceous boundary interval and correlation with the geomagnetic polarity Mar. Micropaleontol., 14: $119-152$.

Chamney, T. P., 1969. Barremian Textulariina, foraminifera from lower Cretaceous beds, Mount Goodenough section, Aklavik Range, District of Mackenzie. Bull. Geol. Surv. Can., 185.

1971. New species of foraminifera, Cretaceous/Jurassic boundary, Arctic Canada. In Pedder, A.E.H., et al. (Eds.), Contributions to Canadian Paleontology. Bull. Geol. Surv. Can., 192:95-109.

Dabagian, N. V., 1969. Foraminifera from the transition beds between Lower and Upper Cretaceous in the Ukrainian Cretaceous. Annu. Soc. Geol. Pol., 39:213-223.

Desai, D., and Banner, F. T., 1987. The evolution of the early Dorothiinae (Foraminiferida). J. Micropaleontol., 6:13-28.

Dieni, I., and Massari, F., 1966. I foraminiferi del Valanginiano superiore di Orosea (Sardegna). Paleontogr. It., 61:75-186.

Dylazanka, M., 1923. Warstwy inoceramowe z lomu w Szymbarku kolo Gorlic. Rocz. Polsk. Towarz. Geol., 1:36-80. 
Fullerton, L. G., Sager, W. W., and Handshumacher, D. W., 1989. Late Jurassic-Early Cretaceous evolution of the eastern Indian Ocean adjacent to northwest Australia. J. Geophys. Res., B94:2937-2953.

Gasiorowski, S. M., 1962. Aptychi from the Dogger, Malm, and Neocomian in the western Carpathians. Studia Geol. Pol., 10.

Geroch, S., 1959. Stratigraphic significance of arenaceous foraminifera in the Carpathian flysch. Paläntol. Zeit., 33:113-122.

1961. Pseudoreophax a new genus of foraminifera from the Neocomian flysch Carpathians. Rocz. Polsk. Towarz. Geol., 31:159165 .

1966. Lower Cretaceous small foraminifera of the Silesian series, Polish Carpathians. Rocz. Polsk. Towarz. Geol., 36:413-480.

Geroch, S., and Nowak, W., 1984. Proposal of zonation for the late Tithonian-late Eocene, based upon arenaceous foraminifera from the outer Carpathians, Poland. In Oertli, H. J. (Ed.), Benthos' 83, 2nd Int. Symp. on Benthic Foraminifers (Pau, April 1983), 225-239.

Geroch, S., and Olszewska, B., 1990. The oldest assemblages of agglutinated foraminifers of the Polish Carpathians. In Hemleben, C., Kaminski, M. A., Kuhnt, W., and Scott, D. B. (Eds.), Taxonomy, Biostratigraphy and Paleoceanography of Agglutinated Foraminifera: Dordrecht (Kluwer Press), 525-538.

Gradstein, F. M., 1983. Paleoecology and stratigraphy of Jurassic abyssal foraminifera in the Blake-Bahama Basin, Deep Sea Drilling Project Site 534. In Sheridan, R. E., Gradstein, F. M., et al., Init. Repts. DSDP, 76: Washington (U.S. Govt. Printing Office), 537-560.

Gradstein, F. M., Gibling, M. R., Jansa, L. F., Kaminski, M. A., Ogg, J. G., Sarti, M., Thurow, J. W., von Rad, U., and Westermann, G.E.G., 1989. Mesozoic stratigraphy of Thakkhola, central Nepal. Dalhousie Univ. Centre for Mar. Geol. Spec. Rept. 1.

Guembel, C., 1862. Die Streitberger Schwammlager und ihre Foraminiferen-Einschlüsse. Jhah. Ver. vaterl. Naturkd. Wüttemb., 18:192238.

Grzybowski, J., 1896. Otwornice czerwonych ilow z Wadowic. Rozp. Wydz. Mat.-Przyr. Akad. Umiejetnosci w Krakowie, Ser. 2, 30:261308.

1898. Otwornice pokladow naftonosnych okolicy Krosna. Rozp. Wydz. Mat.-Przyr. Akad. Umiejetnosci w Krakowie, Ser. 2, 33:257305.

Haeusler, R., 1881. Untersuchungen über die mikroskopischen Strukturverhältnisse der Aagauer Jurakalke mit besonderer Berücksichtigung ihrer Foraminiferenfauna. [Diss. Univ. Zürich].

Helby, R., Morgan, R., and Partridge, A. D., 1987. A palynological zonation of the Australian Mesozoic. In Jell, P. A., (Ed.), Studies in Australian Mesozoic Palynology. Assoc. Australas. Palaeontol. (Sidney), 1-94.

Jansa, L. F., Enos, P., Tucholke, B. E., Gradstein, F. M., and Sheridan, R. E., 1979. Mesozoic-Cenozoic sedimentary formations of the North American Basin, western North Atlantic. In Talwani, M., Hay, W., and Ryan, W.B.F. (Eds.), Deep Drilling Results in the Atlantic Ocean: Continental Margins and Paleo-Environment. Am. Geophys. Union, $3: 1-57$.

Jones, J. P., and Parker, W. K., 1860. On the Rhizopodal fauna of the Mediterranean compared with that of the Italian and some other Tertiary deposits. Quar. J. Geol. Soc. London, 16:292-307.

Kaminski, M. A., Gradstein, F. M., Berggren, W. A., Geroch, S., and Beckmann, J. P., 1988. Agglutinated foraminiferal assemblages from Trinidad: Taxonomy, Stratigraphy and Paleobathymetry. In Gradstein, F. M., and Rögl, F. (Eds.), Proc. 2nd Int. Workshop on Agglutinated Foraminifera (Vienna, 1986), 41:155-228.

Kuhnt, W., and Kaminski, M. A., 1989. Upper Cretaceous deep-water agglutinated benthic foraminiferal assemblages from the western Mediterranean and adjacent areas. In Wiedmann, J. (Ed.), Cretaceous of the Western Tethys. Proc. 3rd Int. Cretaceous Symp., Tübingen, 91-120.

Kuhnt, W., Kaminski, M. A., and Moullade, M., 1989. Deep-water agglutinated benthic foraminiferal assemblages of the upper Cretaceous North Atlantic and its marginal seas. Geol. Rundschau, 78:1121-1140 (DSDP Spec. Vol.).

Kuznetsova, K. I., and Siebold, I., 1978. Foraminifers from the Upper Jurassic and Lower Cretaceous of the eastern Atlantic (DSDP Leg 41, Sites 367 and 370). In Lancelot, Y., and Seibold, E., et al., Init. Repts. DSDP, 41: Washington (U.S. Govt. Printing Office), 515-537.
1974. Distribution of benthonic foraminifera in Upper Jurassic and Lower Cretaceous deposits at Site 261, DSDP Leg 27, in the eastern Indian Ocean. In Veevers, J. J., Heirtzler, J. R., et al., Init. Repts. DSDP, 27, Washington (U.S. Govt. Printing Office), 673-681.

Luterbacher, H., 1972. Foraminifera from the Lower Cretaceous and Upper Jurassic of the northwestern Atlantic. In Hollister, C. D. Ewing, J. I., et al., Init. Repts. DSDP, 11: Washington (U.S. Govt. Printing Office), 561-593.

Maync, W., 1973. Lower Cretaceous foraminiferal fauna from Gorringe Bank, eastern North Atlantic. In Ryan, W.B.F., Hsü, K. J., et al., Init. Repts. DSDP, 13: Washington (U.S. Govt. Printing Office), 10751111.

Mjatliuk, E. V., 1939. Foraminifera of the Upper Jurassic and Lower Cretaceous of the region of the Middle Volga River and the Great Syrte [in Russian]. Trudy VNIGRI, 120:1-76.

Neagu, T., 1972. Cenomanian benthonic foraminifera in the southern part of the eastern Carpathians (Romania). Rocz. Pol.Tow. Geol., 42:3-46.

Nowak, W., 1968. Stomiosphaerids of the Cieszyn Beds (KimmeridgianHauterivian) in the Polish Cieszyn Silesia and their stratigraphical value. Rocz. Pol. Tow. Geol., 38:275-327.

Proto-Decima, F. R., 1974. Leg 27 calcareous nannoplankton. In Veevers, J. J., Heirtzler, J. R., et al., Init. Repts. DSDP, 27: Washington (U.S. Govt. Printing Office), 589-621.

Reuss, A. E., 1845. Die Versteinerungen der bohmischen Kreideformation, Abt. 1: Stuttgart (Schweizerbartsohne Verlagsbuchhandlung).

Riegraf, W., and Luterbacher, H., 1989a. Benthorrische Foraminiferen aus der Unterkreide des »Deep Sea Drilling Project« (Leg 1-79). Geol. Rundschau, 78:1063-1120.

1989 b. Oberjura-Foraminiferen aus dem Nord- und Südatlantik (Deep Sea Drilling Project Leg 1-79). Geol. Rundschau, 78:999-1046.

Schaaf, A., 1985. Un nouveau canevas biochronologique du Crétacé inférieur et moyen: les biozones à radiolaires. Sci. Geol. Bull. $38: 227-269$.

Sclater, J. G., Meinke, L., Bennett, A., and Murphy, C., 1985. The depth of the ocean through the Neogene. In Kennett, J.P. (Ed.), The Miocene Ocean. Geol. Soc. Am. Mem., 163:1-20.

Schultze, F. E., 1875. Zoologische Ergebnisse der Nordseefart vom 21 Juli bis 9 September 1872;1-Rhizopoden. Comm. Wiss. Untersuchung Deutsch. Meere Kiel, Jahresber.: Berlin Jahrg. 2-3.

Sliter, W. V., 1980. Mesozoic foraminifers and deep-sea benthic environments from Deep Sea Drilling Project Sites 415 and 416, Eastern North Atlantic. In Lancelot, Y., Winterer, E. L., et al., Init. Repts. DSDP, 50: Washington (U.S. Govt. Printing Office), 353-428.

Slomka, T., 1986. Statistical approach to study of flysch sedimentation Kimmeridian-Hauterivian Cieszyn Beds, Polish Outer Carpathians. Annu. Soc. Geol. Pol., 56:277-336.

Vašiček, M., 1947. Poznamky k mikrobiostratigrafii magurskeho flyše na Morave. Vest. Stat. Geol. Ust. Ceskoslovenske Republ., 22:235-256.

von Rad, U., Thurow, J., Haq, B. U., Gradstein, F. M., and Ludden, J., 1989. Triassic to Cenozoic evolution of the NW Australian continental margin and the birth of the Indian Ocean (preliminary results of ODP Legs 122 and 123). Geol. Rundschau, 78:1189-1210.

Wickenden, R.T.D., 1932. New species of foraminifera from the Upper Cretaceous of the prairie provinces. Trans. Roy. Soc. Can. Ser. 3 , 26:85-91.

Date of initial receipt: 22 June 1990

Date of acceptance 28 September 1990

Ms 123B-126

TAXONOMY

Systematic Paleontological Descriptions

Genus AMMOBACULITES Cushman, 1910

Ammobaculites sp.

(PI. 5, Figs. 1a,1b)

Description. An extremely coarse species of Ammobaculites having a large spiral portion and a sharp periphery. Interior of test is poorly visible, but the initial spire appears to consist of six chambers. Uniserial portion uncoils tangentially and contains two chambers.

Occurrence. Sample 765C-62R-3, 138-142 cm. 
Genus AMMOBACULOIDES Plummer, 1932

Ammobaculoides sp. cf. A. carpathicus Geroch

$$
\text { (Pl. 5, Figs. 2,3) }
$$

Description. Test elongate, composed of numerous chambers having parallel sides. The most characteristic feature is the long, uniserial portion of the test, which is made up of seven low chambers that slowly increase in size. The initial portion is usually indistinct, but several specimens display a small planispiral portion, which is then followed by several chambers that are either trochospiral or biserial. In other specimens, the coiling of the initial part is not apparent and may be multiserial. Sutures in the uniserial portion are depressed, and the aperture is terminal.

Remarks. Specimens from Hole $765 \mathrm{C}$ are similar to coeval specimens of Ammobaculoides carpathicus from Poland in overall dimensions, external outline, and the shape of the chambers in the uniserial part. However, as our specimens are opaque, their internal structure is not apparent. Thus, we adopted the designation "cf." until the relationship between Indian Ocean and Carpathian specimens can be determined by more detailed study.

Occurrence. Common at the base of Core 123-765C-60R.

\section{Genus AMMODISCOIDES Cushman, 1909 \\ Ammodiscoides sp.}

(PI. 2, Fig. 1)

Description. Test composed of a small, globular proloculus, followed by a coiled tubular chamber, first coiled in a low cone, later planispiral. The cone-shaped initial portion expands at a wide angle, and the test is made up of up to 11 whorls, which increase in size very slowly. Test wall has a rough finish.

Remarks. This form is similar in size and number of whorls to Ammodiscus tenuissimus. We have not observed this form in coeval sediments of the Carpathians.

Occurrence. Basal sample of Hole 765C (Sample 123-765C-62R-4, $25-27 \mathrm{~cm}$ ).

\section{Genus AMMODISCUS Reuss, 1862 Ammodiscus cretaceus (Reuss)}

(Pl. 2, Fig. 2)

Operculina cretaceus Reuss, 1845 , p. 35 , pl. 13, figs. 64-65.

Ammodiscus cretaceus (Reuss) Riegraf and Luterbacher, 1989a, p. 1087, pl. 1, fig. 7.

Description. A relatively large, thick Ammodiscus having a white, finely finished wall.

Occurrences. This well-known form is primarily from Upper Cretaceous to Paleogene flysch-type faunas, but Riegraf and Luterbacher (1989a) reported that it ranges upward from the Tithonian. In Hole 765C, this species is present consistently, but in low numbers in the Hauterivian to Barremian "Biofacies B" assemblages.

\section{Ammodiscus sp. A}

Description. A small, compressed form comprised of up to five whorls, with a white, finely finished wall with much cement. The last whorl of the test is disproportionately wide, which distinguishes it from other species of Ammodiscus.

Remarks. The Upper Cretaceous species Ammodiscus planus Loeblich, 1940 also displays a wide last whorl, but is thinner and has more whorls than Ammodiscus sp. A.

\section{Ammodiscus sp. B \\ (Pl. 2, Figs. 4,5)}

Description. A large, compressed species made up of few whorls, coiled somewhat irregularly, with a thin agglutinated wall and a rough surface.

Remarks. Differs from other species of Ammodiscus in its irregular coiling and matte finish.

Occurrence. Mostly within Core 123-765C-59R.

\section{Ammodiscus sp. C}

(P1. 2, Fig. 6)

Ammodiscus nussbachensis (Noth) Riegraf and Luterbacher, 1989a (in part), p. 1090 , pl. 1, fig. 8 .
Description. An extremely robust species composed of few whorls with a thick, coarsely agglutinated wall.

At Site 261, Riegraf and Luterbacher (1989a) reported this species as Ammodiscus nussbachensis from Core 261-31R-4. In Hole 765C, we found two specimens (Samples 123-765C-60R-5, 8-12 cm, and 123765C-62R-4, 25-27 cm.)

\section{Ammodiscus tenuissimus (Guembel)}

(P1. 2, Fig. 3)

Spirillina tenuissimus Guembel, 1862, p. 214, pl. 4, figs. 12a, 12b.

Description. An extremely thin species having a globular proloculus, followed by a coiled tubular chamber of 10 or more whorls. Diameter of the tube increases very slowly. Wall has a rough finish.

Occurrence. Common from Cores $123-765 \mathrm{C}-62$ to $-49 \mathrm{R}$.

Genus AMMOLAGENA Eimer and Fickert, 1899 Ammolagena clavata (Jones and Parker)

$$
\text { (Pl. 2, Fig. 16) }
$$

Trochammina squamata var. clavata, Jones and Parker, 1860, p. 306.

Occurrence. In Hole $765 \mathrm{C}$, this species occurs only in association with Inoceramus prisms in Cores 123-765C-62R and -61R. Kuznetsova (1974) reported Ammolagena from a single sample at Site 261. Apart from this occurrence, this species has not been reported from Lower Cretaceous DSDP material.

\section{Genus ARENOTURRISPIRILLINA Tairov, 1956 Arenoturrispirillina jeletzkyi Chamney}

(P1. 2, Fig. 8)

Arenoturrispirillina jeletzkyi Chamney, 1971, p. 106, pl. 18A, figs. 6-9, pl. 18B, figs. 6-9.

Description. Test in the form of a wide cone, composed of many whorls. Cone expands at a wide angle, which distinguishes it from Turritellella.

\section{Genus ASCHEMOCELLA Vyalov, 1966}

Aschemocella spp.

$$
\text { (Pl. 3, Fig. 17) }
$$

Description. Fragments of robust, elongated chambers that resemble A. carpathicus (Neagu).

Occurrence. Two samples (123-765C-62R-2, 138-142 cm, and 123765C-61R-1, 18-21 cm.)

\section{Genus BATHYSIPHON M. Sars, 1872 Bathysiphon spp. \\ (PI. 1, Figs. 1, 2)}

Remarks. We placed all finely agglutinated tubular fragments in Bathysiphon sp.

\author{
Genus BIGENERINA d'Orbigny, 1826 \\ Bigenerina sp. \\ (PI. 7, Figs. 1, 2)
}

Description. Test initially biserial, later uncoiling, and finally uniserial. The initial biserial portion is tapered, about one-third the length of the test, composed of about five sets of chambers. This is followed by about two sets of larger, globular chambers that are staggered, transitional to uniserial, and finally, by about two globular uniserial chambers.

Occurrence. In Hole $765 \mathrm{C}$, this form occurs mainly within Core 123-765C-60R. Riegraf and Luterbacher (1989a) reported specimens from Hole 261 as Bigenerina jurassica (Haeusler), which was reported to range from Callovian to Valanginian.

Genus BULBOBACULITES Maync, 1952 Bulbobaculites inconstans (Bartenstein and Brandt) (P1. 4, Figs. 9, 10)

Haplophragmium inconstans Bartenstein and Brandt, Kuznetsova, 1974, pl. 1 , figs. $10 \mathrm{a}, 10 \mathrm{~b}$.

Description. Initial streptospiral portion followed by several globular chambers. 
Remarks. We place this species in Bulbobaculites because of its simple, nonalveolar wall structure.

Occurrence. Base of Cores 123-765C-62R to -57R. Abundant in Core 123-765C-61R.

Genus DENDROPHRYA Wright, 1891

Dendrophrya latissima Grzybowski

Dendrophrya latissima Grzybowski, 1898, p. 17, pl. 10, fig. 8 .

Psamminopelta anglesiaensis (Crespin) Krasheninnikov and Pflauman, 1978 , p. 567, pl. 1, figs. 6,7.

Description. A wide, flattened tube having a thin wall. Found as fragments.

Occurrence. Rare in Cores $123-765 \mathrm{C}-59 \mathrm{R}$ to -56R.

Genus GAUDRYINA d'Orbigny, 1839

Gaudryina sp. A

(Pl. 6, Figs. 11, 12)

Description. A coarsely agglutinated species, laterally compressed, with a tapered multiserial portion, followed by a long biserial part having parallel sides and high chambers.

Occurrence. Restricted to the upper portion of the studied interval (Cores $123-765 \mathrm{C}-58 \mathrm{R}$ to $-56 \mathrm{R}$ ).

Genus GLOMOSPIRA Rzehak, 1885

Glomospira charoides (Jones and Parker)

Trochammina squamata var. charoides, Jones and Parker, 1860, p. 306.

Glomospira arctica Chamney, 1969, p. 16, pl. 2, figs. 7a, 7b.

Glomospira subarctica saturna Chamney, 1969, p. 17, pl. 2, figs. 10-12.

Glomospira variabilis (Kubler and Zwingli) Luterbacher, 1972, pl. 1, figs. 4-6.

Glomospira charoides (Parker and Jones) Geroch and Olszewska, 1990.

Description. Test tubular, coiling about a vertical axis, and having four to five whorls in the outermost layer of coils. Coiling can be variable, and the axis of coiling may shift, of the tubular chamber may become irregular in the later portion of the test. Chamney (1969) distinguished his species by this irregular coiling. Authors working on Lower Cretaceous sequences are divided between the use of the Jurassic name Glomospira variabilis and the modern name Glomospira charoides.

\section{Glomospira gordialis (Jones and Parker)}

(Pl. 2, Fig. 4)

Trochammina squamata var. gordialis, Jones and Parker, 1860, p. 306.

Description. Test composed of a proloculus, followed by an undivided tubular second chamber that is streptospirally coiled about a common plane, usually in five or six whorls. Coiling is open, not enrolled, and the umbilicus is usually visible and is depressed.

Remarks. Some authors lump $G$. gordialis together with $G$. charoides. In our material, G. gordialis has more cement than $G$. charoides and is often white in color. There is little difficulty in separating these two forms.

\section{Glomospira irregularis (Grzybowski)}

$$
\text { (Pl. 2, Fig. 11, 12) }
$$

Ammodiscus irregularis Grzybowski, 1896, p. 285, pl. 11, figs. 2-3.

Glomospira irregularis (Grzybowski) Bartenstein, 1974, p. 686, pl. 2, figs. 41-44.

Description. A streptospirally enrolled species having a coarse wall. Occurrence. In low numbers from Cores $123-765 \mathrm{C}-61 \mathrm{R}$ to $-47 \mathrm{R}$. Riegraf and Luterbacher (1989) reported that this species ranges upward from the Callovian.

$$
\text { Glomospira sp. aff. G. serpens (Grzybowski) }
$$

$$
\text { (PI. 2, Fig. 13) }
$$

aff. Ammodiscus serpens Grzybowski, 1898.

Description. Test oval in outline, coiled in a triloculine manner, with each successive whorl approximately $60^{\circ}$ from the preceding. The Upper
Cretaceous to Paleogene species Glomospira serpens differs by being more regular and more elongated.

\section{Glomospira sp. aff. G. diffundens (Cushman and Renz)}

Description. More robust than $G$. gordialis, with a broader coiled chamber. Resembles the Upper Cretaceous to Paleogene species Glomospira diffundens Cushman and Renz, 1946.

Occurrence. Rare in the upper portion of the studied interval, in Core 123-765C-50R

\section{Genus GLOMOSPIRELLA Plummer, 1945 \\ Glomospirella gaultina (Berthelin)}

(Pl. 2, Fig. 15)

Ammodiscus gaultinus Berthelin, 1880, p. 19, pl. 1, fig. 13.

Ammodiscus gaultinus Berthelin (Maync, 1973), p. 1081, pl. 1, figs. 4-5.

Glomospirella gaultina (Berthelin) Kuznetsova, 1974, pl. 1, figs. 2a, 2b.

Description. Test initially trochospiral or coiled about a wobbly axis, later planispiral, finely agglutinated, white in color.

Remarks. For a more complete reference list, see Maync (1973).

Occurrence. Present in low numbers from Cores 123-765C-61R to $-47 R$.

$$
\text { Glomospirella (Annectina) sp. }
$$

$$
\text { (Pl. 2, Fig. 14) }
$$

Description. Test large, thick, oval in outline. Initial coil is inclined $90^{\circ}$ to later whorls.

Remarks. The Paleogene species Glomospirella biedai Samuel, 1977 also has an initial whorl inclined $90^{\circ}$ to later whorls, but this species differs in its narrow chamber and compressed test. In G. biedai, the initial nonplanispiral portion is much smaller than in this species. Because we used the genus Glomospira for milioline-coiled forms as well as for forms that are coiled about a single plane, we do not differentiate the genus Annectina, which reportedly differs from Glomospirella in its miliolinecoiled initial portion.

Occurrence. Found in a single sample (123-765C-61R-1, 79-82 cm).

\section{Genus HAPLOPHRAGMOIDES Cushman, 1910 \\ Haplophragmoides kirki Wickenden}

(Pl. 4, Figs. 1a-2)

Haplophragmoides kirki Wickenden, 1932, p. 85, pl. 1, fig. 1.

Description. Test planispiral, composed of four to five globular chambers.

Remarks. This species was originally described from the Upper Cretaceous of Alberta.

Occurrence. Common in Core 123-765C-61R.

$$
\begin{gathered}
\text { Haplophragmoides sp. A } \\
\text { (Pl. 4, Figs. 6a, 6b) }
\end{gathered}
$$

Description. Test relatively large, generally compressed, somewhat evolute, with five to seven chambers in the last whorl, biumbilicate, circular in outline, with subacute periphery. Wall coarsely agglutinated. Chambers triangular, sutures indistinct or depressed slightly in the final whorl.

$$
\begin{aligned}
& \text { Haplophragmoides sp. B } \\
& \text { (Pl. 4, Figs. 3-4b) }
\end{aligned}
$$

Description. Test small, involute, with five chambers in the last whorl and a rounded periphery. Aperture slitlike. Wall coarsely agglutinated.

Occurrence. Found in Cores $123-765 \mathrm{C}-60 \mathrm{R}$ and $-61 \mathrm{R}$.

$$
\text { Haplophragmoides sp. C. }
$$

Description. Test thick, coarsely agglutinated, composed of five and one-half chambers, with broadly rounded periphery.

Occurrence. Found in only one sample (123-765C-60R-3, 83-87 cm).

$$
\begin{aligned}
& \text { Haplophragmoides sp. D } \\
& \text { (Pl. 4, Figs. 7a, 7b) }
\end{aligned}
$$

Description. Test flat, evolute, circular in outline, with subacute periphery and about nine chambers in the last whorl. 
Occurrence. Found in the upper Core $123-765 \mathrm{C}-62 \mathrm{R}$ and lower part of Core 123-765C-61R.

Genus HIPPOCREPINA Parker, in Dawson, 1870 Hippocrepina depressa Vasicek

(Pl. 1, Figs. 7, 8)

Hippocrepina depressa Vasicek, 1947, p. 243, pl. 1, figs. 1-2.

Hippocrepina depressa Vasicek Bartenstein, 1974, p. 684, pl. 2, figs. 23-26.

Description. A small, laterally compressed conical tube that may be arched and may have annular constrictions at irregular intervals. Wall finely agglutinated, finely finished, white in color.

Occurrence. Found in low numbers from Cores 123-765C-62R to $-56 \mathrm{R}$. Common in Core $123-765 \mathrm{C}-60 \mathrm{R}$.

\section{Genus HORMOSINA Brady, 1879 \\ Hormosina cf. crassa Geroch}

Description. More coarsely agglutinated than other species of the genus Hormosina. Ovoid to spherical chambers having thick connections. Generally, broken into one-chamber fragments, rarely two chambers having chamber connections are preserved; however, sometimes exhibiting an arcuate chamber arrangement. Differs from Hormosinella distans in its broader chamber-connections, a more roughly finished surface, and a probably thicker wall.

\section{Hormosina excelsa (Dylazanka)}

(Pl. 3, Figs. 2, 3)

Hyperammina excelsa Dylazanka, 1923, p. 66, pl. 1, fig. 3.

Description. Test finely agglutinated, composed of two or more elongate chambers having thick connecting stolons.

Remarks. This species has not been previously reported from the Lower Cretaceous. Nevertheless, it is identical to the typical Upper Cretaceous to Paleocene form.

Occurrence. Found in two samples in Core 123-765C-61R.

\section{Hormosina crassa Geroch}

(PI. 3, Figs. 7, 8)

Hormosina ovulum crassa Geroch, 1966, p. 439, fig. 6 .

Saccammina lathrami Tappan Sliter, 1980, pl. 1, fig. 7.

Pelosina crassa (Geroch) Riegraf and Luterbacher, 1989, p. 1085, pl. 1, figs. 2-3.

Description. Ovoid rectilinear chambers, connected by relatively thick stolons.

Occurrence. Found in Cores $123-765 \mathrm{C}-61 \mathrm{R}$ to $-56 \mathrm{R}$.

\section{Genus HORMOSINELLA Shchedrina, 1969 \\ Hormosinella sp.}

(Pl. 3, Fig. 9)

Description. Single compressed chambers, flask-shaped, connected by thin stolons.

Occurrence. Found in a single sample (123-765C-60R-5, 8-12 cm).

Genus HYPERAMMINA Brady, 1878

Hyperammina dilatata Grzybowski

(Pl. 1, Figs. 12-14)

Hyperammina dilatata Grzybowski, 1896, p. 274, pl. 8, fig. 17a-17b.

Description. Saclike single chambers, with broadly rounded base, tapered toward the top, with a large aperture.

Remarks. This species was first described from the Upper Cretaceous of the Polish Carpathians. To our knowledge, it has not been previously described from Lower Cretaceous DSDP/ODP material.

Occurrence. Found in Cores $123-765 \mathrm{C}-61 \mathrm{R}$ to $-57 \mathrm{R}$.

\section{Hyperammina spp.}

(Pl. 1, Figs. 9, 10)

Remarks. We placed all finely agglutinated tubular forms having a preserved proloculus in Hyperammina spp. A number of authors have used the name " $H$. gaultina" for Lower Cretaceous DSDP material.
Occurrence. Found in low numbers from Cores $123-765 \mathrm{C}-61 \mathrm{R}$ to $-57 \mathrm{R}$.

\author{
Genus KALAMOPSIS de Folin, 1883 \\ Kalamopsis sp. aff. $K$. grzybowskii (Dylazanka) \\ (Pl. 3, Figs. 5, 6)
}

Kalamopsis grzybowskii (Dylazanka) Bartenstein, 1974, p. 685, pl. 1 , figs. $31-34$; pl. 2, figs. $27-35$.

Kalamopsis grzybowskii (Dylazanka) Riegraf and Luterbacher, 1989b, p. 1019 , pl. 1 , figs. 4,5 .

Description. Test tubular, with constrictions and occasional partitions at irregular intervals. Chambers usually break at the point of constriction. Wall very fincly agglutinated, with a fine finish, white in color.

Remarks. This form is smaller than the typical Paleogene species $K$. grzybowskii and has a proportionally shorter tubular chamber. Bartenstein (1974) considered this form to be transitional to Hyperammina gaultina Ten Dam.

Occurrence. In Hole $765 \mathrm{C}$, this species was found in Cores 123765C-60R and -59R. Riegraf and Luterbacher reported its range as Kimmeridgian to Eocene in the North Atlantic (Sites 105, 367, 368, 370, 398). Its oldest occurrence in the Polish Carpathians, reported as Kalamopsis sp., is in the upper Tithonian (Geroch and Olszewska, 1990).

\section{Genus LAGENAMMINA Rhumbler, 1911}

Lagenammina spp.

(PI. 1, Figs. 18, 19)

Remarks. We placed all flask-shaped unilocular forms having tapering apertural necks in Lagenammina spp.

\section{Genus LITUOTUBA Rhumbler, 1895 \\ Lituotuba spp.}

Description. Rare, coarsely agglutinated forms that probably belong in Lituotuba.

Occurrence. Found only in the upper part of the studied section (Cores 123-765C-56R to -47R).

Marssonella(?) sp.

(Pl. 7, Fig. 8)

Deseription. A conical, coarsely agglutinated species of Marssonella (or Protomarssonella) having a flat apertural face and flush, indistinct sutures. Wall is coarse and does not contain carbonate cement. Largest specimens have three and one-half chambers in the final whorl. We did not observe any specimens having a biserial part.

Remarks. Differs from Dorothia conula (Reuss), illustrated by Kuznetsova (1974) from Site 261, in its circular cross section and flat apertural face.

Occurrence. Restricted to Cores $123-765 \mathrm{C}-62 \mathrm{R}$ and $-61 \mathrm{R}$.

Paratrochammina sp.

(Pl. 6, Fig. 5.)

Remarks. A few specimens with globular chambers that have been historically ascribed to Trochammina globigeriniformis by most authors.

\section{Genus PARATROCHAMMINOIDES Majzon, 1943}

Paratrochamminoides spp.

$$
\text { (P1. 5, Fig. 13) }
$$

Sorosphaera confusa Brady Bartenstein, 1974, pl. 3, fig. 18.

Description. Streptospirally coiled, with globular, rounded chambers and an areal aperture. Specimens from the base of Hole $765 \mathrm{C}$ are small and finely agglutinated. Specimens from the top of the studied interval are more coarsely agglutinated. The small, finely agglutinated specimens resemble $P$. intricatus Krasheninnikov.

Occurrence. Found in Cores $123-765 \mathrm{C}-61 \mathrm{R}$ to -56R. Generally rare.

Genus PRAECYSTAMMINA Krasheninnikov, 1973

Praecystammina sp.

(Pl. 5, Fig. 13)

Description. A rare, enigmatic form having two chambers visible from the outside. 
Genus PRAEDOROTHIA Desai and Banner, 1987

Praedorothia praehauteriviana Dieni and Massari, 1966

(Pl. 6, Figs. 7, 8)

Dorothia praehauteriviana Dieni and Massari, 1966, pl. 2, figs. 23, 24, pl. 10, figs. 9-13.

Marssonella hauteriviana Moullade, Maync, 1973, p. 1086, pl. 1, figs. 35-37.

Praedorothia praehauteriviana (Dieni and Massari) Desai and Banner, 1987 , p. 18 , pl. 4 , figs. $2 \mathrm{a}-2 \mathrm{~d}$

Description. An elongate form having subparallel sides. Sutures in the biserial part are depressed, and the apertural face is rounded.

Remarks. Riegraf and Luterbacher (1989a) considered this species synonymous with Marssonella ouachensis Sigal, 1952, and reported this form as Praedorothia praehauteriviana.

Occurrence. This species forms a distinctive correlation horizon in the Atlantic, Tethys, and Pacific. In Hole 765C, the species was found in turbidite layers in Cores $123-765 \mathrm{C}-56 \mathrm{R}$ and $-58 \mathrm{R}$.

\section{Praedorothia sp. A}

(PI. 6, Figs. 9, 10)

Description. A small species having a smooth, finely finished wall. Initial trochospiral part consists of about four whorls, with initially about seven chambers in the first whorl, rapidly reducing to about four and one-half chambers per whorl, then three, and finally two chambers per whorl. The majority of specimens do not show biserial development.

Occurrence. We found this species in Cores 123-765C-61R to -59R.

\section{Praedorothia sp, B}

(Pl. 7, Fig. 9)

Textularia foeda Reuss Maync, 1973, p. 1084, pl. 1, fig. 22.

Textularia inversa (Terquem) Kuznetsova, 1974, pl. 1, figs. 8a-8c.

Description. Test initially trochospiral, later biserial, with aperture at the base of the last chamber. Initial trochospiral part is bluntly rounded, thicker in cross section than the biserial part, and consists of one to two whorls, with about four chambers per whorl. Biserial part immediately follows. Chambers in the biserial part are high, and the apertural face is strongly convex and rounded. Wall very finely finished, perfectly smooth, white in color.

Remarks. This species is characterized by its long biserial part and white color. It was reported as Textularia inversa by Kuznetsova (1974) from Site 261. However, Textularia is typically a shallow-water genus with pseudopores and calcareous cement. Praedorothia sp. B does not contain carbonate material in its wall. Resembles the species Dorothia zedlerae Moullade.

Occurrence. Found in Cores $123-765 \mathrm{C}-61 \mathrm{R}$ to $-59 \mathrm{R}$.

Genus PSAMMOSPHAERA Schultze, 1875

Psammosphaera fusca Schultze

(Pl. 1, Figs. 16, 17)

Psammosphaera fusca Schultze, 1875, p. 113, pl. 2, figs. 8a-8f.

Description. Test unilocular, spherical or subspherical, free or attached, composed of a single layer of sand grains in a matrix of smaller fine silt grains. Aperture a single small hole, but small spaces between the grains may also serve as apertures.

Occurrence. Restricted to coarse sediments in Cores 123-765-62R and $-61 R$.

Psammosphaera sp.

(Pl. 1, Fig. 15)

(?)Psammosphaera sp. Geroch and Olszewska, 1990, pl. 2, figs. 20, 21.

Description. Test unilocular, spherical, composed of uniformly smal agglutinated grains having a thick wall and a single, small, round opening without a lip that serves as an aperture.

Occurrence. Ranges from Cores $123-765 C-62 R$ to -56R. Abundan in Core 123-765C-62R.

\section{Genus PSEUDOBOLIVINA Wiesner, 1931}

Pseudobolivina spp.

Description. Minute, predominently biserial forms having a narrow, acutely tapered, initial portion.

Occurrence. Common in Sample 123-765C-60R-2, 37-40 cm.

Genus PSEUDOREOPHAX Geroch, 1961

Pseudoreophax cisownicensis Geroch

(Pl. 7, Figs. 5, 6)

Pseudoreophax cisownicensis Geroch, 1961, p. 159, pl. 17, figs. 1-5. Ammobaculites irregularis (Guembel) Sliter, 1980, pl. 2, fig. 14. Bigenerina jurassica (Haeusler) Gradstein, 1983, pl. 1, fig. 1.

Pseudoreophax cisownicensis Geroch, Riegraf and Luterbacher, 1989a, p. 1093, pl. 2, fig. 22.

Description. Test rectilinear or arched, early chambers trochospirally arranged, later uniserial. Chamber connections, seen in well-silicified topotype material, are asymmetric, and uniserial chambers appear to be rotated with respect to one another.

Occurrence. Ranges from Cores $123-765 \mathrm{C}-61 \mathrm{R}$ to $-59 \mathrm{R}$, common in some samples.

\section{Genus REOPHAX Montfort, 1808 \\ Reophax duplex Grzybowski}

(Pl. 3, Fig. 11)

Reophax duplex Grzybowski, 1896, p. 276, pl. 8, figs. 23, 24.

Description. Test relatively small, composed of two (rarely three) embracing spherical chambers of almost equal dimension. Wall coarse, with a rough surface.

Remarks. This species is common in Upper Cretaceous flysch-type assemblages, but to our knowledge has not been previously described from Lower Cretaceous DSDP/ODP material.

Occurrence. Found in low numbers from Cores 123-765C-61R to $-49 \mathrm{R}$.

\section{Reophax helveticus (Haeusler)}

(Pl. 3, Figs. 12-14)

Dentalina helveticus Haeusler, 1881, p. 34, pl. 2, fig. 45.

Reophax helveticus (Haeusler) Riegraf and Luterbacher, 1989b, p. 1023, pl. 1, figs. 19-22.

Reophax multilocularis (Haeusler) Luterbacher, 1972, pl. 1, fig. 3.

Description. Test rectilinear, chambers rounded to flask-shaped, wall relatively coarse with a rough finish.

Remarks. Riegraf and Luterbacher (1989b) interpreted the variability of $R$. helveticus broadly, and included forms with flask-shaped chambers (e.g., Pl. 3, Figs. 12,13) as well as forms with more rounded chambers (e.g., Pl. 3, Fig. 15), which Luterbacher (1972) referred to $R$. multilocularis.

\section{Reophax sp. B}

Description. A small species of Reophax having globular chambers. Occurrence. Found in a single sample (123-765C-61R-2, 96-100 $\mathrm{cm})$.

Reophax sp. C
(Pl. 3, Fig. 10)

Description. A rather robust, coarsely agglutinated species of Reophax having few chambers.

Occurrence. This species occurs only in association with turbidites in Cores 123-765C-62R and -61R.

\section{Genus RHABDAMMINA M. Sars in Carpenter, 1869 Rhabdammina spp.}

(Pl. 1, Figs. 3, 4)

Description. We placed all tubular fragments attributable to Rhab dammina in this category. Most specimens are straight and can be placed in Rhabdammina cylindrica Glaessner. A few specimens display central swellings and are similar to Rhabdammina linearis Brady. 
Genus RHIZAMMINA Brady, 1879

Rhizammina spp.

(PI. 1, Figs. 5, 6)

Remarks. We placed all curved tubular fragments having a thin wall in this category.

\section{Genus SACCAMINNA M. Sars in Carpenter, 1869 Saccammina sp. \\ (Pl. 1, Fig. 20)}

Remarks. We placed all round unilocular forms in this category.

Genus SPIROPLECTAMMINA Cushman, 1927 Spiroplectammina sp.

Description. Small, compressed species having a broad initial whorl. Similar to S. suprajurassica (Schwager) illustrated by Luterbacher (1972).

\section{Genus SUBREOPHAX Saidova, 1975 \\ Subreophax spp. \\ (Pl. 3, Figs. 15, 16)}

Description. Form having round, compressed chambers arranged in a rectilinear series. Similar to the Upper Cretaceous species Subreophax scalaria (Grzybowski).

\section{Genus THALMANNAMMINA Porkorny, 1951 \\ Thalmannammina sp. A}

(Pl. 5, Figs. 4, 5)

Description. Close-coiled, compact form having a finely finished wall and a distinct, areal aperture. Coiled in the U-shaped manner typical of the genus Thalmannammina. Forms such as these are not known from sediments older than Barremian (Th. Neagu, pers. comm. to MAK, 1990).

Occurrence. Found in Cores $123-765 \mathrm{C}-62 \mathrm{R}$ to $-59 \mathrm{R}$.

\section{Thalmannammina sp. B}

$$
\text { (PI. 5, Figs. 6-9) }
$$

Description. Small, relatively coarsely agglutinated, streptospiral form having five globular chambers visible from the exterior. Aperture areal.

Occurrence. Found in Cores $123-765 \mathrm{C}-62 \mathrm{R}$ to $-60 \mathrm{R}$. Common in Core $123-765 \mathrm{C}-61 \mathrm{R}$.

Genus TROCHAMMINA Parker and Jones, 1859

Trochammina abrupta Geroch

(PI. 5, Figs. 14a-15; Pl. 6, Figs. 1a-2c)

Trochammina abrupta Geroch, 1959, p. 118, pl. 12, figs. 1-3.

Trochammina abrupta Geroch, Riegraf and Luterbacher, 1989a, p. 1092, pl. 2 , figs. 4,5 .

Description. Test planoconvex, with seven to eight triangular chambers in the final whorl, circular in outline. Spiral side is flat. Sutures are flush or slightly depressed. Two morphotypes are recognized in our material. The first morphotype has a high, convex umbilical side with a small, slightly depressed umbilicus (Pl. 5, Fig. 15; Pl. 6, Figs. 1a, 1b). The second type is broader, with more open coiling, the umbilical side is lower, and the umbilicus is more pronounced. This type corresponds to the topotypes from Poland and to the specimen illustrated by Riegraf and Luterbacher (1989a).

Occurrence. Found from Cores $123-765 C-62 R$ to $-57 R$. This species is common from Cores $123-765 \mathrm{C}-62 \mathrm{R}$ to $-59 \mathrm{R}$.

\section{Trochammina quinqueloba Geroch, 1959}

$$
\text { (Pl. 6, Figs. 3-4b) }
$$

Trochammina quinqueloba Geroch, 1959, p. 118, pl. 12, figs. 1-3. Trochammina quinqueloba Geroch, Kuznetsova, 1974, pl. 1, figs. 5a-5c.
Description. Test planoconvex, with a high conical umbilical side. Five chambers in the last whorl. Compares well with the type specimens from Poland.

Occurrence. This species is abundant in Core $123-765 \mathrm{C}-62 \mathrm{R}$ and characterizes the oldest benthic assemblage in Hole $765 \mathrm{C}$.

$$
\begin{aligned}
& \text { Trochammina sp. A } \\
& \text { (P1. 6, Figs. 6a-6c) }
\end{aligned}
$$

Description. Test large, biconvex, circular, or slightly lobate in outline. Spiral side is convex, with about three whorls, and nine chambers in the last whorl. In edge view, the test is lenticular. Sutures are indistinct, depressed slightly in the youngest chambers.

Remarks. Differs form other species of Trochammina in possessing a convex spiral side. Resembles the Upper Cretaceous species Trochammina albertensis from the Cretaceous interior of North America in possessing a convex spiral side.

Occurrence. Restricted to Core 123-765C-62R.

$$
\begin{aligned}
& \text { Genus TROCHAMMINOIDES Cushman, } 1910 \\
& \text { Trochamminoides sp. }
\end{aligned}
$$$$
\text { (Pl. 5, Fig. 10) }
$$

Description. A robust form composed of three whorls, with about seven rounded chambers in the last whorl.

\section{Genus TURRITELLELLA Rhumbler, 1904 \\ Turritellella sp. \\ (Pl. 2, Fig. 7)}

Description. Test small, finely agglutinated, composed of a tight helical coil of about four whorls.

Occurrence. Found in two samples $(123-765 \mathrm{C}-59 \mathrm{R}-5,78-80 \mathrm{~cm}$, and $-61 \mathrm{R}-2,96-100 \mathrm{~cm})$.

\section{Genus UVIGERINAMMINA Majzon, 1943 \\ Uvigerinammina spp. \\ (Pl. 7, Figs. 10-13)}

Description. Test initially trochospiral with three chambers per whorl, later reducing to uniserial. Uniserial part is often bent with respect to the trochospiral part. Aperture on a produced neck.

\section{Genus VERNEUILINOIDES Loeblich and Tappan, 1949 Verneuilinoides neocomiensis (Mjatliuk)}

$$
\text { (Pl. 7, Fig. 15) }
$$

Verneuilina neocomiensis Mjatliuk, 1939, p. 50, pl. 1, figs. 12, 13. Verneuilinoides neocomiensis (Mjatliuk) Kuznetsova, 1974, pl. 1, figs. $6 \mathrm{a}-6 \mathrm{c}$.

Description. Test triserial, tending to become biserial in the last whorl, tapered at both ends.

Remarks. According to Mjatliuk (1939), V. neocomiensis has 7 to 10 sets of chambers over a length of 0.50 to $0.57 \mathrm{~mm}$. The species $V$. subfiliformis Bartenstein, 1952 was described as possessing 12 sets of chambers over a similar length. Bartenstein (1952) suggested a gradual replacement of $V$. neocomiensis by $V$. subfiliformis during the Barremian. Maync (1973) considered both species to be synonymous because of transitional forms.

In our material, we can separate a more slender form having parallel sides (Pl. 7, Fig. 16) from the typical, stouter V. neocomiensis. Both forms co-occur at the base of the studied section.

$$
\text { Verneuilinoides } \mathrm{sp} \text {. }
$$$$
\text { (PI. 7, Fig. 16) }
$$

Description. Slender, triserial species having parallel sides. 


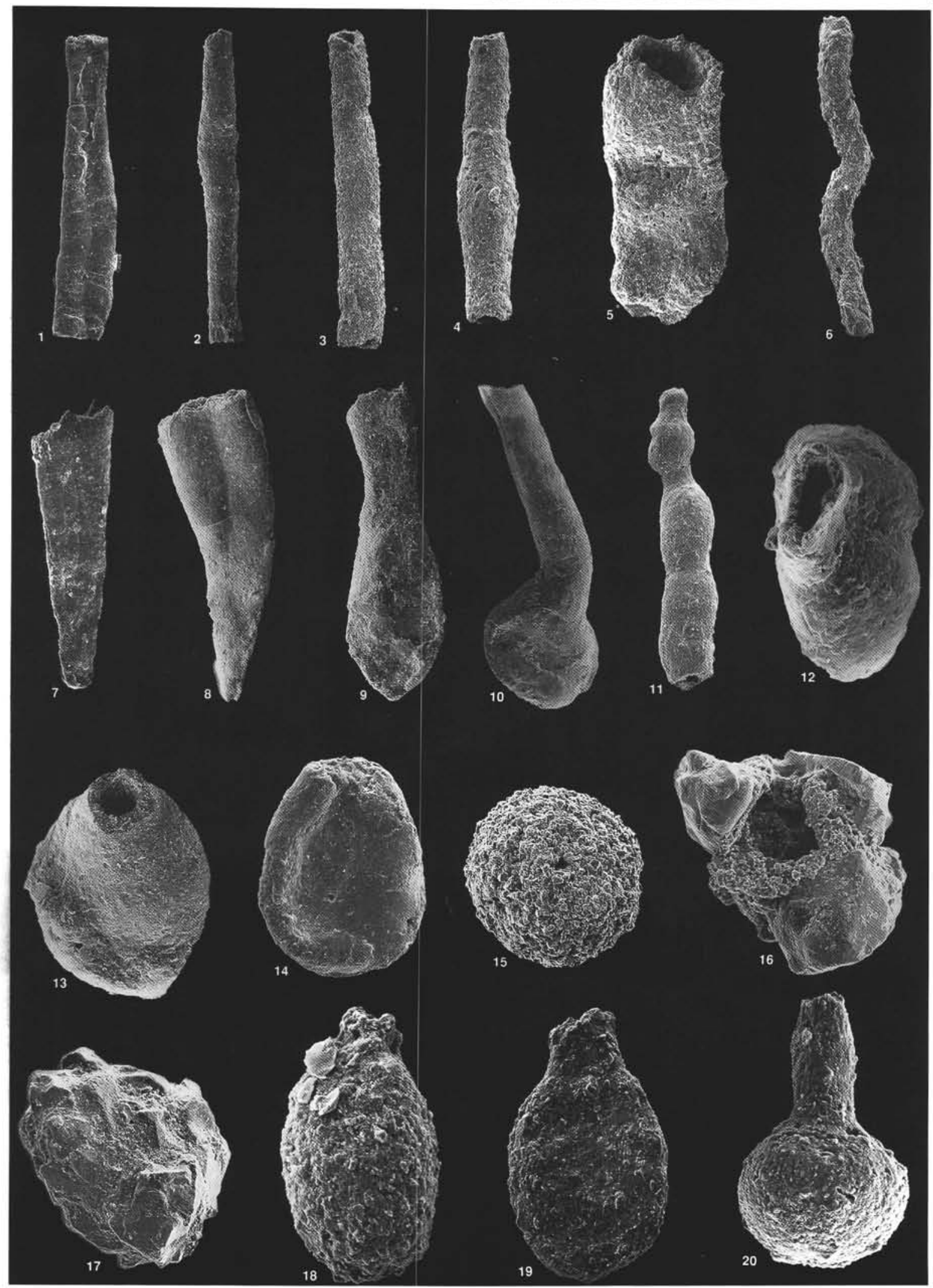

Plate 1. 1. Bathysiphon sp., 62R-4, 25-27 cm, x47. 2. Bathysiphon sp., 64R-4, 25-27 cm, x83. 3. Rhabdammina sp., 60R-2, $119-121 \mathrm{~cm}, \mathrm{x} 120.4$. Rhabdammina linearis, $61 \mathrm{R}-2,96-100 \mathrm{~cm}, \mathrm{x} 73.5$. Rhizammina sp., $62 \mathrm{R}-4,25-27 \mathrm{~cm}, \mathrm{x} 60.6$. Rhizammina sp., $61 \mathrm{R}-1,91-95 \mathrm{~cm}, \mathrm{x} 75.7$. Hippocrepina depressa, 62R-4, 25-27 cm, x125. 8. Hippocrepina depressa, 60R-1, 18-21 cm, x54. 9. Hyperammina sp., 60R-3, 83-87 cm, x104. 10. Hyperammina $\mathrm{sp} ., 62 \mathrm{R}-4,25-27 \mathrm{~cm}, \mathrm{x} 36.11$. Hyperamminoides $\mathrm{sp} ., 61 \mathrm{R}-1,91-95 \mathrm{~cm}, \mathrm{x} 78.12$. Hyperammina dilatata, $60 \mathrm{R}-2,119-125 \mathrm{~cm}, \mathrm{x} 109.13$. Hyperammina dilatata, 60R-3, 83-87 cm, x129. 14. Hyperammina dilatata, 60R-2, 119-125 cm, x99. 15. Psammosphaera laevigata, 61R-1, 79-82 cm, x130. 16. Psammosphaera fusca, 61R-CC, x179. 17. Psammosphaera fusca, 62R-3, 138-142 cm, x99. 18. Lagenammina sp., 61R-1, 91-95 cm, x166. 19. Lagenammina sp., 60R-CC, x112. 20. Saccammina sp., 61R-1, 91-95 cm, x187. 


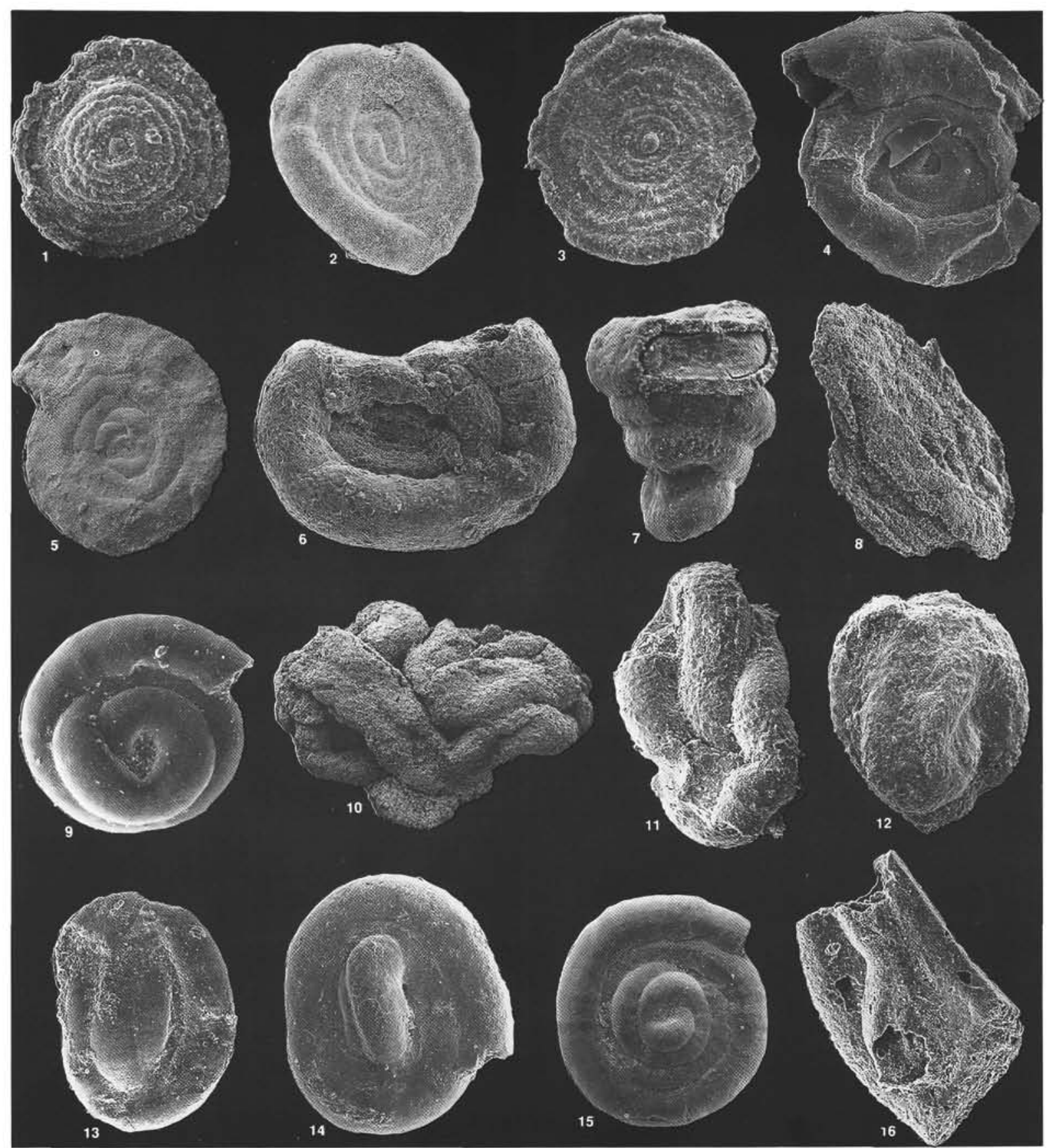

Plate 2. 1. Ammodiscoides sp., 62R-4, 25-27 cm, x122. 2. Ammodiscus cretaceus, 50R-3, 111-115 cm, x85. 3. Ammodiscus tenuissimus, 62R-4, 25-27 $\mathrm{cm}, \mathrm{x} 117.4$. Ammodiscus sp. B (coarse, flat), $62 \mathrm{R}-4,25-27 \mathrm{~cm}, \mathrm{x} 68.5$. Ammodiscus $\mathrm{sp}$. B (coarse, flat), 59R-2, 121-124 cm, x39. 6. Ammodiscus sp. $\mathrm{C}$ (robust), 60R-5, 8-12 cm, x39. 7. Turritellella sp., 61R-2, 96-100 cm, x140. 8. Arenoturispirillina jeletzkyi, 59R-2, 121-124 cm, x146. 9. Glomospira gordialis, 61R-2, 96-100 cm, x140. 10. Glomospira sp., 55R-1, 30-34 cm, x44. 11. Glomospira irregularis, 61R-1, 91-95 cm, x75. 12. Glomospira irregularis, 60R-CC, x99. 13. Glomospira sp. aff. G. serpens, 59R-CC, x109. 14. Glomospirella (Annectina) sp., 61R-1, 79-81 cm, x99. 15. Glomospirella gaultina, $61 \mathrm{R}-2,96-100 \mathrm{~cm}, \mathrm{x} 104$. 16. Ammolagena clavata, 61 R-5, 58-60 cm, x131. 


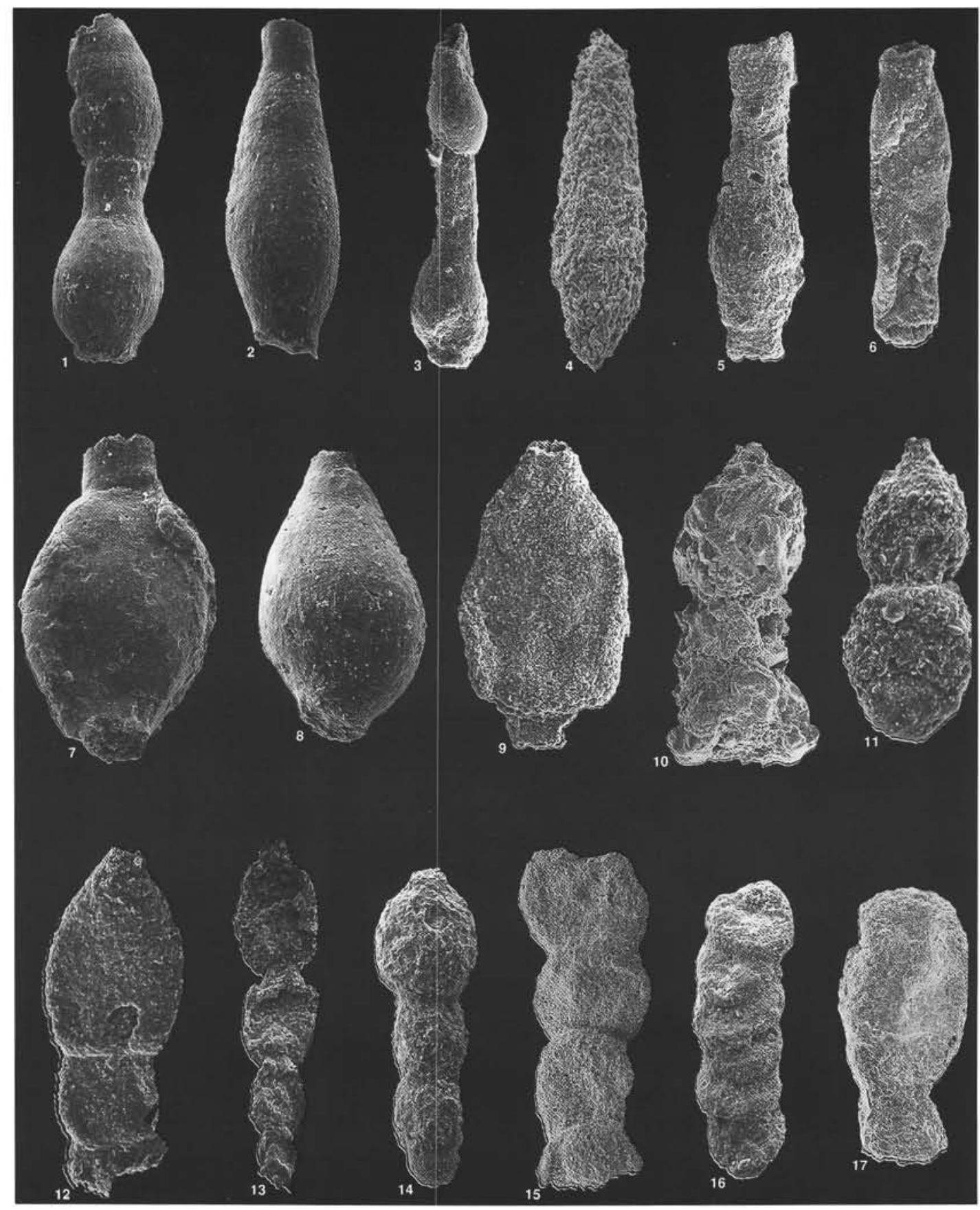

Plate 3. 1. Hormosina cf. crassa, $61 \mathrm{R}-2,96-100 \mathrm{~cm}$, x133. 2. Hormosina excelsa, 61 R-1, 79-82 cm, x166. 3. Hormosina excelsa, 61R-1, 79-82 cm, x91. 4. Kalamopsis sp., 61R-CC, x133. 5,6. Kalamopsis sp. aff. K. grzybowskii, 59R-2, 121-125 cm, x140. 7. Hormosina ovulum s.1., 60R-CC, x88. 8. Hormosina ovulum s.1., 61R-2, 96-100 cm, x133. 9. Hormosinella sp., 60R-5, 8-12 cm, x104. 10. Reophax sp. C (coarse), 62R-3, 138-142 cm, x78. 11. Reophax duplex, 60R-2, 37-40 cm, x148, 12. Reophax helveticus, $60 \mathrm{R}-2,37-40 \mathrm{~cm}, \times 130$. 13. Reophax helveticus, $60 \mathrm{R}-2,37-40 \mathrm{~cm}, \mathrm{x} 96.14$. Reophax sp. B, 60R-CC, x99. 15. Subreophax sp., 57R-CC, x85. 16. Subreophax sp., 57R-CC, x96. 17. Aschemonella sp., 62R-2, $138-142, \mathrm{x} 79$. 


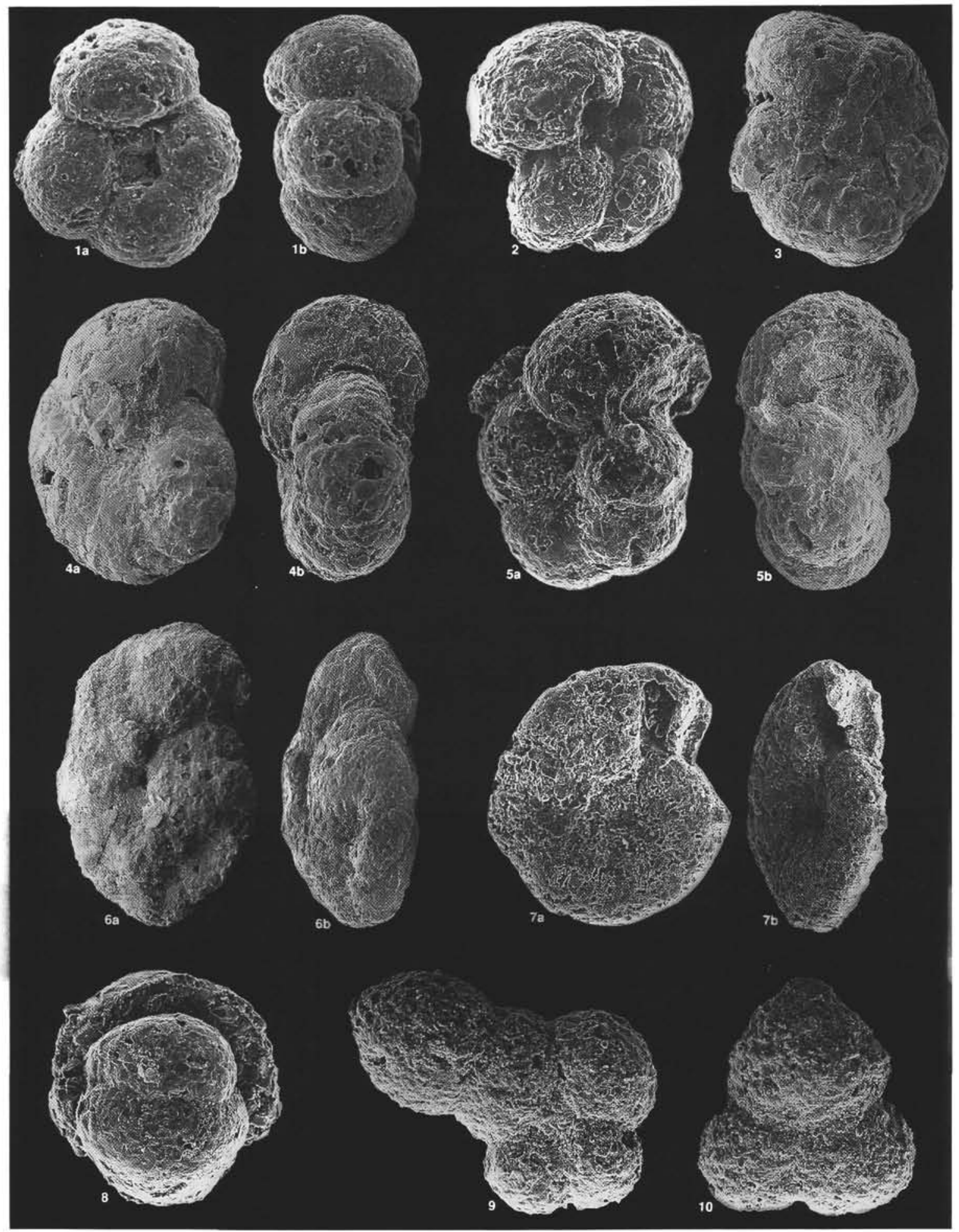

Plate 4. 1a, 1b. Haplophragmoides kirki, 61R-1, 79-82 cm, x117. 2. Haplophragmoides kirki, 61R-1, 79-82 cm, x130. 3. Haplophragmoides sp. B (5-chamb), 60R-1, 18-21 cm, x166. 4a, 4b. Haplophragmoides sp. B, 60R-1, 18-21 cm, x130. 5a, 5b. Haplophragmoides sp. B, 61R-1, 79-82 cm, $\mathrm{x} 130.6 \mathrm{a}, 6 \mathrm{~b}$. Haplophragmoides sp. A flat, $60 \mathrm{R}-1,18-21 \mathrm{~cm}, \mathrm{x} 75.7 \mathrm{a}, 7 \mathrm{~b}$. Haplophragmoides sp. D (evolute), 61R-CC, $\mathrm{x} 107.8$. Haplophragmoides sp. C (broad), 60R-5, 8-12 cm, x117. 9. Bulbobaculites inconstans, 60R-3, 83-87 cm, x182. 10. Bulbobaculites inconstans, $60 \mathrm{R}-3,83-87 \mathrm{~cm}, \mathrm{x} 180$. 


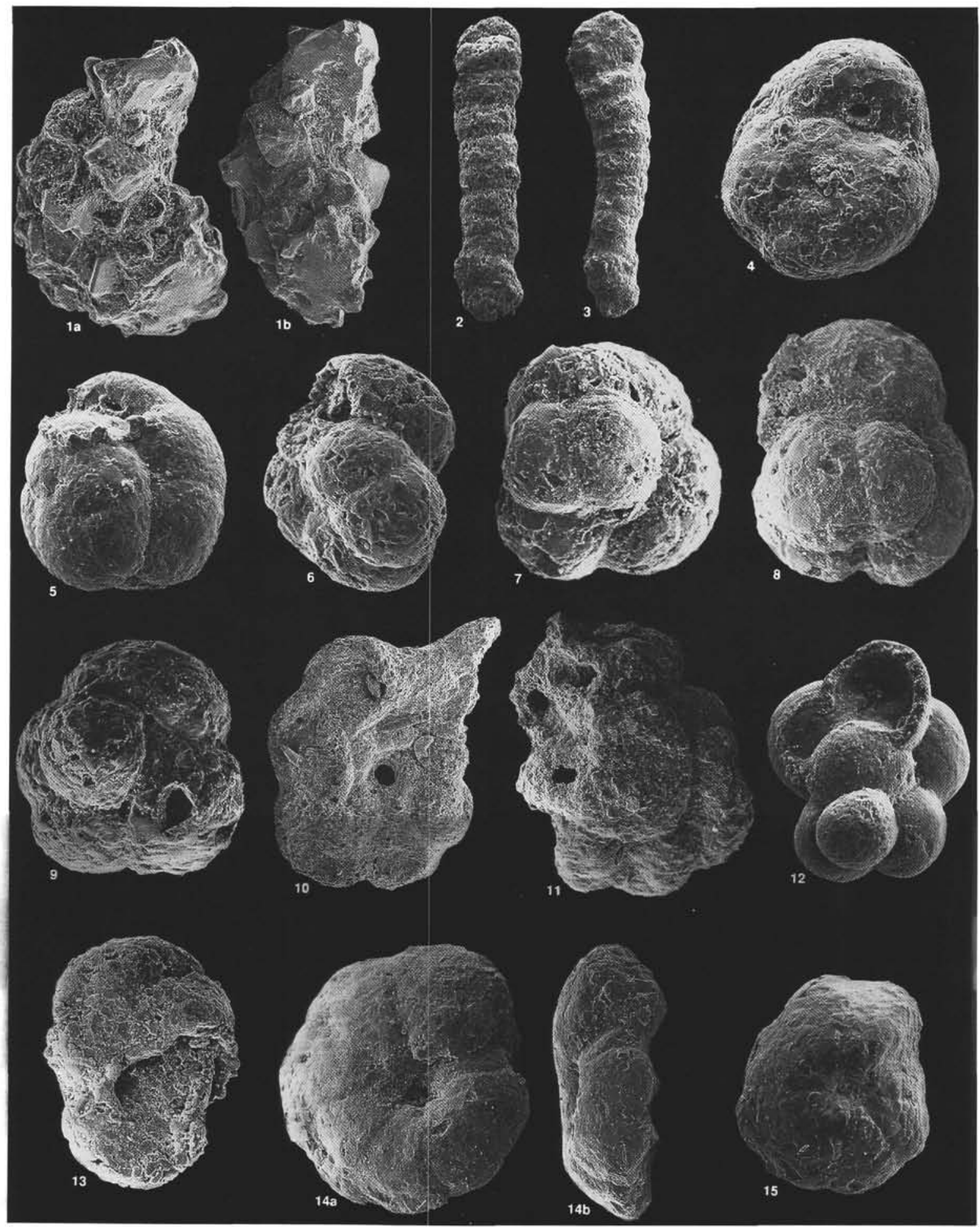

Plate 5. 1a, 1b. Ammobaculites sp. (coarse), 62R-3, 138-142 cm, x99. 2. Ammobaculoides sp. cf. A. carpathicus, 57R-CC, x62. 3. Ammobaculoides sp.cf. A. carpathicus, 60R-CC, x60. 4. Thalmannammina sp. A (smooth), 60R-5, 8-12 cm, x135. 5. Thalmannammina sp. A (smooth), 60R-2, 37-40 $\mathrm{cm}$, x96. 6. Thalmannammina sp. B (5-chamb), 61R-1, 91-95 cm, x140. 7. Thalmannammina sp. B (5-chamb.), 61R-1, 91-95 cm, x177. 8. Thalmannammina sp. B (5-chamb.), x177. 9. Thalmannammina sp. B (5-chamb.), 60R-5, 8-12 cm, x170. 10. Trochamminoides sp., 61R-CC, $\times 29.11$. Paratrochamminoides sp., 60R-3, 83-87 cm, $x 81.12$. Paratrochamminoides $\mathrm{sp} ., 61 \mathrm{R}-1,91-95 \mathrm{~cm}, \mathrm{x} 156.13$. ?Praecystammina sp., 60R-5, 8-12 cm, $\mathrm{x} 142$. 14a, 14b. Trochammina abrupta (low-spired), 60R-3, 83-87 cm, x112. 15. Trochammina abrupta (high-spired), 60R-3, 83-87 cm, x138. 


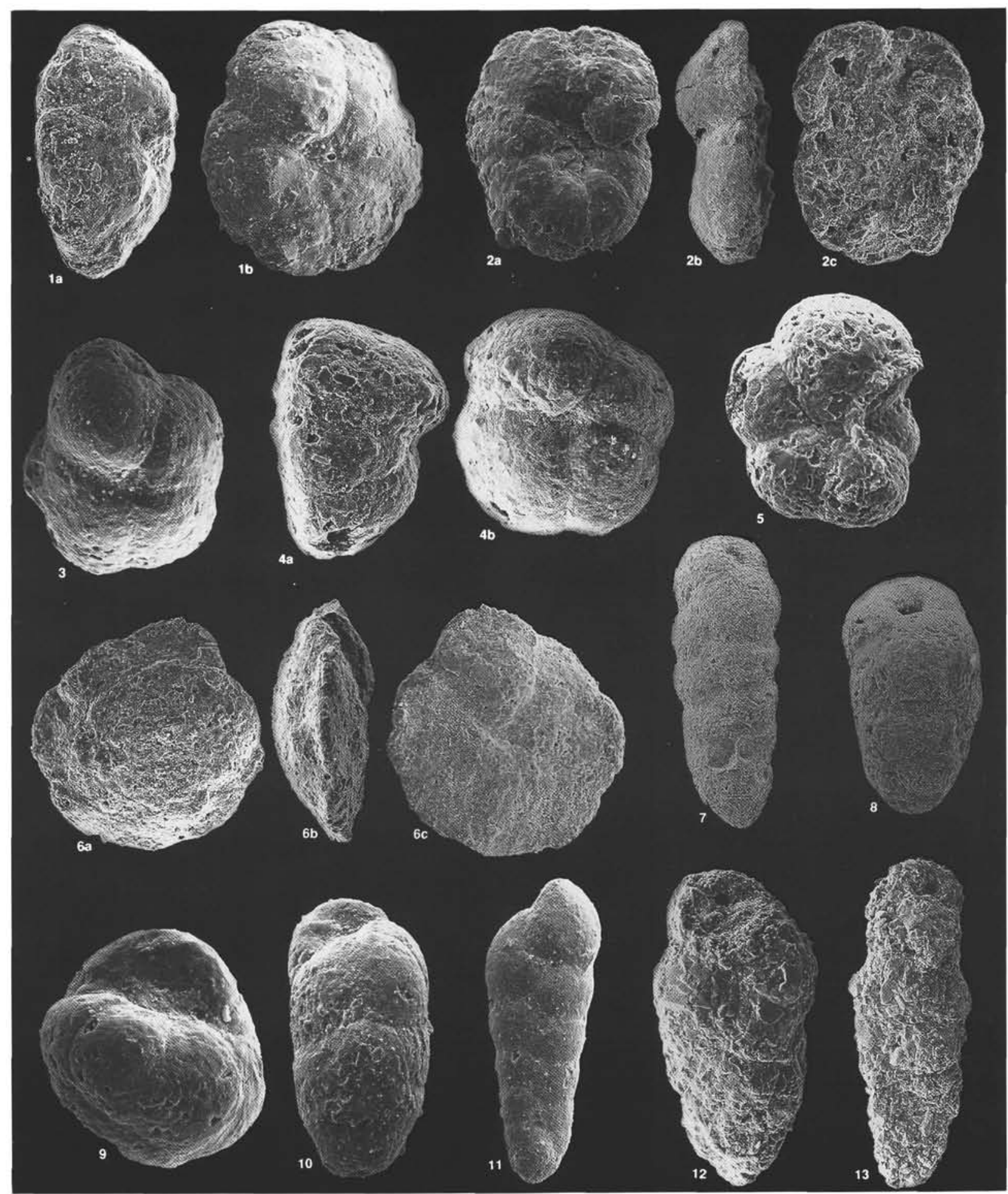

Plate 6. 1a,1b. Trochammina abrupta (high-spired), 60R-3, 83-87 cm, x139. 2a-2c. Trochammina abrupta (low-spired), 61R-1, 79-84 cm, x82. 3. Trochammina quinqueloba, $61 \mathrm{R}-2,96-100 \mathrm{~cm}, \mathrm{x} 166.4 \mathrm{a}, 4 \mathrm{~b}$. Trochammina quinqueloba, 60R-5, 8-12 cm, $\times 185.5$. Paratrochammina sp., 61R-1, 91-95 $\mathrm{cm}, \mathrm{x} 130.6 \mathrm{a}-6 \mathrm{c}$. Trochammina sp. A (biconvex), 62R-3, 138-142 cm, x86. 7. Praedorothia praehauteriviana, 56R-4, 144-148 cm, x64. 8. Praedorothia praehauteriviana, $56 \mathrm{R}-4,144-148 \mathrm{~cm}, \mathrm{x} 84.9$. Praedorothia $\mathrm{sp}$. A (smooth), 61R-1, 91-95 cm, x239. 10. Praedorothia sp. A (smooth), 61R-2, 96-100 $\mathrm{cm}, \mathrm{x} 161$. 11. Praedorothia sp. B, 61R-1, 91-95 cm, x86. 12. Gaudryina sp. A, 60R-3, 83-87 cm, x150. 13. Gaudryina sp. A, 60R-3, 83-87 cm, x97. 


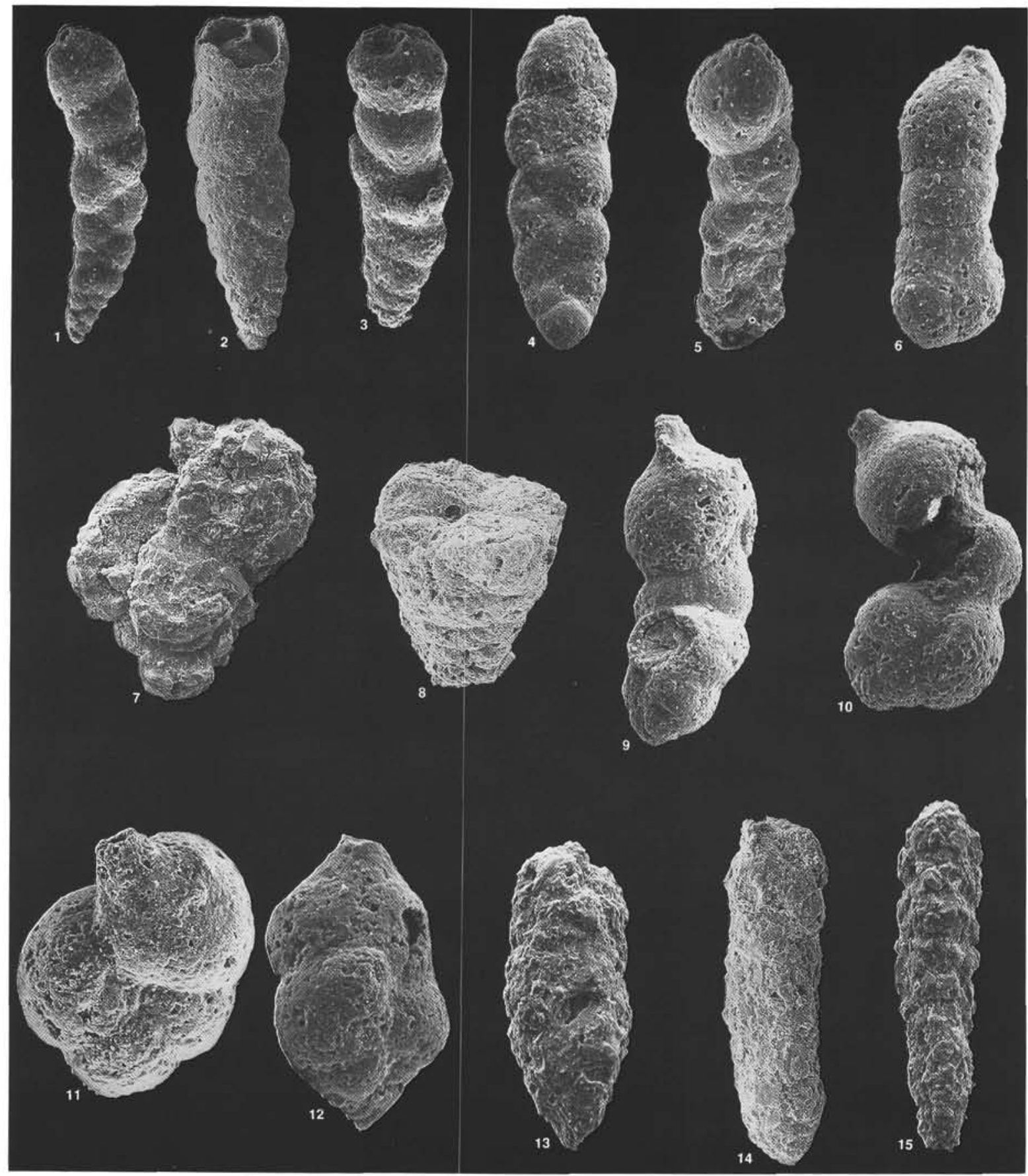

Plate 7. 1. Bigenerina sp., $60 \mathrm{R}-2,37-40 \mathrm{~cm}, \mathrm{x} 120$. 2. Bigenerina sp., $60 \mathrm{R}-5,8-12 \mathrm{~cm}, \mathrm{x} 140.3$. Pseudobolivina $\mathrm{sp} ., 60 \mathrm{R}-2,37-40 \mathrm{~cm}, \mathrm{x} 130,4$. Pseudobolivina sp., 60R-2, 37-40 cm, x140. 5. Pseudoreophax cisownicensis, 61 R-1,91-95 cm, x146. 6. Pseudoreophax cisownicensis, 61R-2, 96-100 $\mathrm{cm}, \mathrm{x} 130.7$. Eggerella sp., 60R-3, 83-87 cm, x98. 8. Marssonella? sp. (conical), 61R-CC, x179. 9. Uvigerinammina sp., 61R-2, 96-100 cm, x130. 10. Uvigerinammina sp., 61R-2, 96-100 cm, x125. 11. Uvigerinammina sp., 61R-CC, x216. 12. Uvigerinammina $\mathrm{sp} ., 61 \mathrm{R}-2,96-100 \mathrm{~cm}, \mathrm{x} 187.13$. Verneuilinoides neocomiensis, $60 \mathrm{R}-2,37-40 \mathrm{~cm}, \mathrm{x} 114$. 14. Verneuilinoides (?transitional form), 60R-3, 83-87 cm, x114. 15. Verneuilinoides sp. (slender), 62R-1, 53-56 cm, x114. 


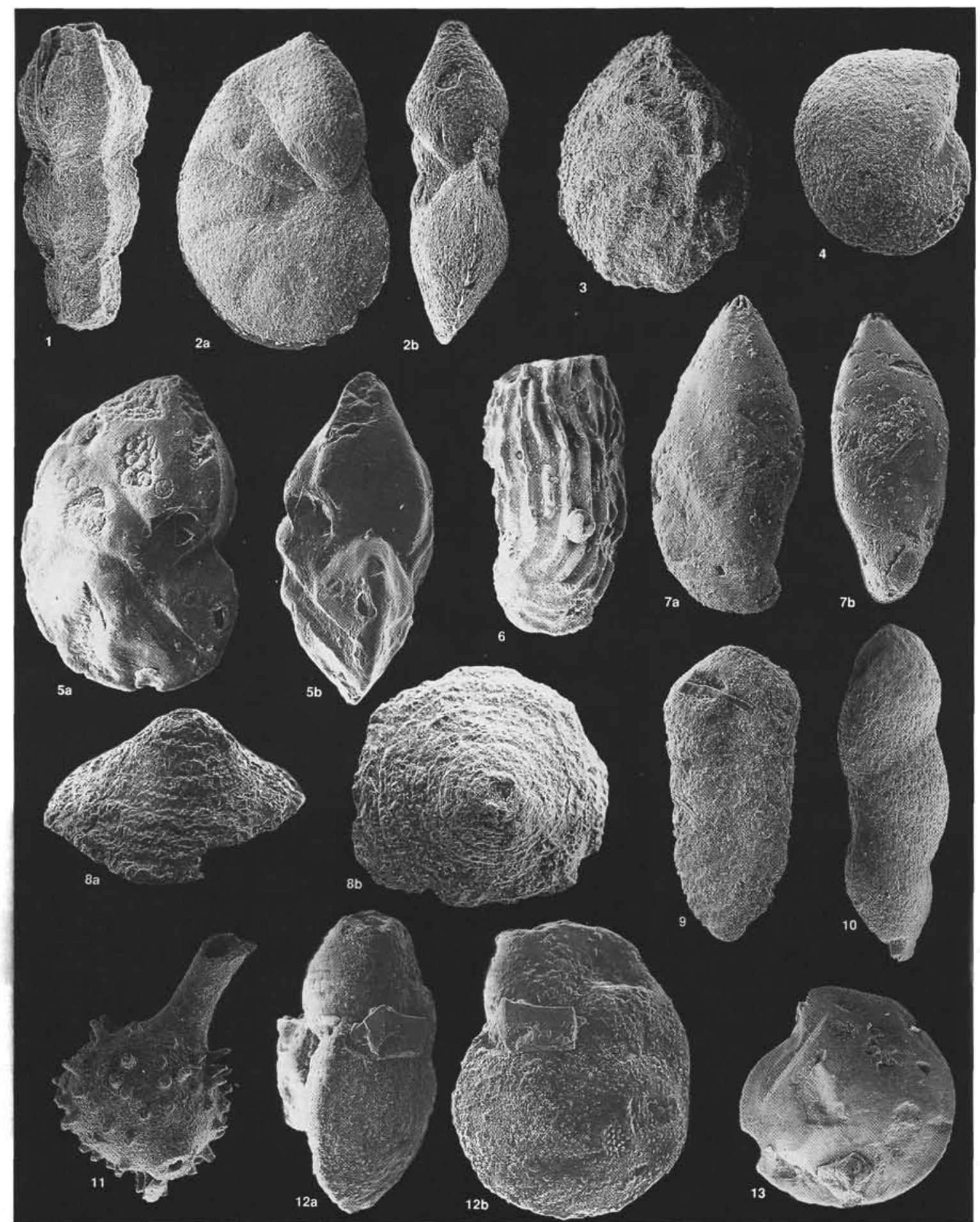

Plate 8. 1. Nodosaria obscura, $56 \mathrm{R}-4,144-148 \mathrm{~cm}, \times 98.2$ a, 2b. Lenticulina subalata, $56 \mathrm{R}-4,144-148 \mathrm{~cm}, \mathrm{x} 76$. 3. Lenticulina guttata, $56 \mathrm{R}-4,144-148$ $\mathrm{cm}, \mathrm{x} 84.4$. Lenticulina sp. aff. L. nodosa, $58 \mathrm{R}-2,10-14 \mathrm{~cm}, \mathrm{x} 89.5 \mathrm{a}, 5 \mathrm{~b}$. Lenticulina sp. aff. L. saxonica, 56R-4, 144-148 cm, x90. 6. Vaginulinopsis sp. aff. reticulosa, 56R-4, 144-148 cm, x90. 7a, 7b. Vaginulopsis sp., 56R-4, 144-148 cm, x101. 8a, 8b. Paalzowella feifeli, 56R-CC, x94. 9. Lingulina loryi, 56R-4, 144-148 cm, x100. 10. Pyrulina longa, 56R-CC, $\mathrm{x} 70.11$. Ramulina aculeata, $56 \mathrm{R}-4,144-148 \mathrm{~cm}, \mathrm{x} 60$. 12a, 12b. Gavellinella sp., 56R-4, $144-148 \mathrm{~cm}, \mathrm{x} 112$. 13. Epistomina caracolla, $56 \mathrm{R}-\mathrm{CC}, \mathrm{x} 56$. 
APPENDIX A

Agglutinated Foraminifers in Hole 765C

\begin{tabular}{|c|c|c|c|c|c|c|c|c|c|c|c|}
\hline Core: & $47 \mathrm{R}-3$ & $48 \mathrm{R}-1$ & $49 \mathrm{R}-3$ & $49 R-6$ & $50 \mathrm{R}-2$ & $50 \mathrm{R}-3$ & 51R-CC & $52 \mathrm{R}-3$ & $53 R-7$ & $55 \mathrm{R}-2$ & $56 \mathrm{R}-1$ \\
\hline Interval $(\mathrm{cm})$ : & $9-13$ & $106-110$ & $69-75$ & $7-11$ & $66-70$ & $111-115$ & - & $75-79$ & $55-59$ & $72-76$ & $134-136$ \\
\hline Depth (mbsf): & 790.5 & 797.9 & 810 & 813.9 & 817.8 & 819.7 & 834.5 & 838.3 & 853.4 & 865.2 & 873.8 \\
\hline Age: & Apt. & Barrem. & Barrem. & Barrem. & Barrem. & Barrem. & Barrem. & Barrem. & Haut. & Haut. & Valan. \\
\hline No. of species & 6 & 8 & 3 & 8 & 3 & 4 & 1 & 3 & 1 & & 15 \\
\hline Bathysiphon spp. & $\mathrm{F}$ & $\mathrm{F}$ & & $\mathrm{F}$ & & & & & & & \\
\hline Rhizammina spp. & $\mathrm{F}$ & F & $\mathrm{R}$ & $\mathrm{F}$ & $\mathrm{F}$ & $\mathrm{C}$ & $\mathbf{R}$ & C & & $\mathbf{P}$ & A \\
\hline Glomospira charoides & $\mathrm{F}$ & $\mathrm{F}$ & $\mathrm{F}$ & $\mathrm{R}$ & & $\mathrm{R}$ & & $\bar{R}$ & $\mathbf{R}$ & $\mathrm{P}$ & C \\
\hline Glomospirella gaultina & $\mathbf{R}$ & $\mathrm{R}$ & & & & & & & & & \\
\hline Glomospira irregularis & $\mathbf{R}$ & $\mathbf{R}$ & & & & & & & & & \\
\hline Ammodiscus cretaceus & $\mathrm{F}$ & $\mathrm{R}$ & F & $\mathrm{R}$ & & $\mathrm{R}$ & & & & & $\mathbf{R}$ \\
\hline Lituotuba spp. & & $\mathrm{R}$ & & & & & & & & & \\
\hline Glomospira sp. aff. G. serpens & & $\mathrm{R}$ & & $\mathrm{R}$ & & & & & & & \\
\hline Glomospira gordialis & & & & $\mathrm{R}$ & & & & & & $\mathbf{P}$ & $\mathrm{F}$ \\
\hline Reophax duplex & & & & $\mathrm{R}$ & & & & & & & $\mathrm{R}$ \\
\hline Ammodiscus tenuissimus & & & & $\mathrm{R}$ & F & & & & & & $\mathbf{R}$ \\
\hline Glomospira sp. aff. G. diffundens & & & & & $\mathrm{R}$ & $\mathrm{R}$ & & & & & \\
\hline Ammodiscus sp. A (wide whorl) & & & & & & & & $\mathbf{R}$ & & & $\mathbf{R}$ \\
\hline Lagenammina spp. & & & & & & & & & & $\mathrm{P}$ & \\
\hline Dendrophrya latissima & & & & & & & & & & & $\mathrm{F}$ \\
\hline Rhabdammina spp. & & & & & & & & & & & $\mathbf{R}$ \\
\hline Hippocrepina depressa & & & & & & & & & & & $\mathrm{R}$ \\
\hline Subreophax spp. & & & & & & & & & & & \\
\hline Saccammina sp. & & & & & & & & & & & $\mathrm{R}$ \\
\hline Paratrochamminoides spp. & & & & & & & & & & & $\mathrm{R}$ \\
\hline Paratrochammina spp. & & & & & & & & & & & $\mathrm{R}$ \\
\hline Haplophragmoides sp. A (flat) & & & & & & & & & & & C \\
\hline
\end{tabular}

Hormosina crassa

Reophax helveticus

Spiroplectammina sp.

Gaudryina sp. A (coarse)

Psammosphaera sp.

Praedorothia praehauteriviana

Verneuilinoides $\mathrm{sp}$. (slender)

Hyperammina dilatata

Arenoturrispirilina jeletzkyi

Bulbobaculites inconstans

Trochammina abrupta

Ammobaculoides sp.

Hyperammina spp.

"Ammodiscus sp. B (coarse, irreg. flat)"

Verneuilinoides neocomiensis

(?)Praecystammina sp.

Praedorothia sp. A (smooth)

Kalamopsis sp. aff. K. grzybowskii

Recurvoides sp. A (smooth)

Praedorothia sp. B (biserial)

Haplophragmoides kirki

Pseudoreophax cisownicensis

Gaudryina filiformis

Turritellella sp.

Bigenerina sp.

Aschemocella spp.

Trochammina quinqueloba

Haplophragmoides sp. B (five-chamb. round)

Pseudobolivina spp.

"Trochammina abrupta, (low-spired)"

Textularia sp. (coarse)

"Recurvoides sp. B (coarse, 5 chamb)"

"Eggerella sp. (coarse, flaring)"

"Haplophragmoides sp. C (thick, convex)"

Ammodiscus sp. C (robust)

Haplophragmoides sp. (broad)

Hormosinella sp.

Trochamminoides sp.

Uvigerinammina spp.

Psammosphaera fusca

Glomospirella (Annectina) sp.

Hormosina excelsa

Hormosina cf. crassa

Reophax sp. B (globular chamber)

Marssonella sp. (conical)

Ammolagena clavata

Haplophragmoides sp. D (flat evolute)

Reophax sp. C (coarse)

"Trochammina sp. A (large, biconvex)"

Ammobaculites sp. (coarse)

Ammodiscoides sp. 
APPENDIX A (continued).

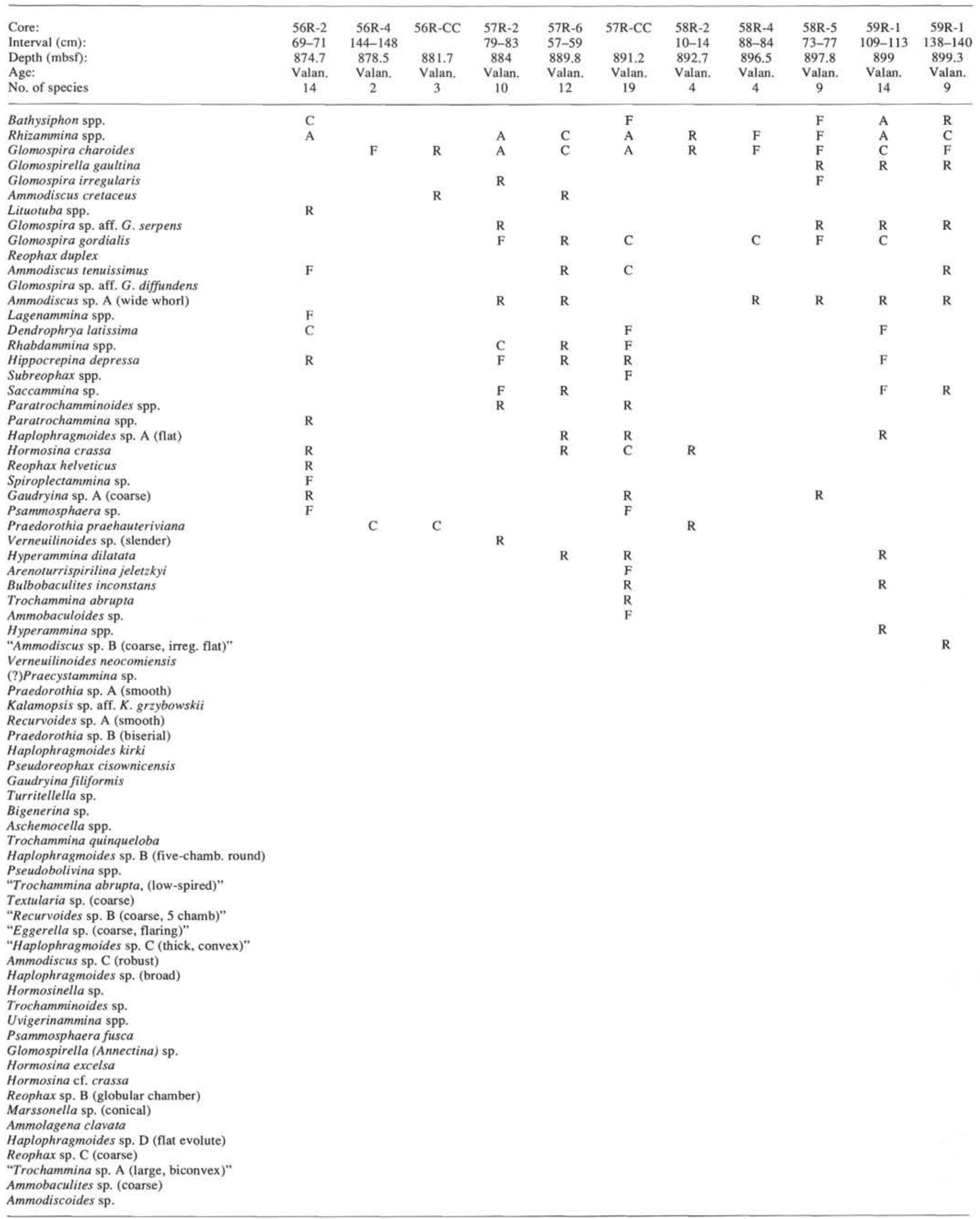


APPENDIX A (continued).

\begin{tabular}{|c|c|c|c|c|c|c|c|c|c|c|c|}
\hline Core: & $59 \mathrm{R}-2$ & $59 \mathrm{R}-5$ & 59R-CC & $60 \mathrm{R}-1$ & $60 \mathrm{R}-2$ & $60 \mathrm{R}-2$ & $60 R-3$ & $60 \mathrm{R}-5$ & $60 \mathrm{R}-\mathrm{CC}$ & $61 \mathrm{R}-1$ & $61 \mathrm{R}-1$ \\
\hline Interval $(\mathrm{cm})$ : & $121-125$ & $78-80$ & & $18-21$ & $37-40$ & $119-122$ & $83-87$ & $8-12$ & & $79-82$ & $91-95$ \\
\hline Depth (mbsf): & 900.6 & 904.8 & 907.5 & 907.7 & 909.4 & 910.2 & 912.3 & 913.6 & 916.9 & 917.7 & 917.8 \\
\hline $\begin{array}{l}\text { Age: } \\
\text { No. of species }\end{array}$ & $\begin{array}{c}\text { Valan. } \\
20\end{array}$ & $\begin{array}{c}\text { Berr. } \\
22\end{array}$ & $\begin{array}{c}\text { Berr. } \\
24\end{array}$ & $\begin{array}{c}\text { Berr. } \\
32\end{array}$ & $\begin{array}{c}\text { Berr. } \\
24\end{array}$ & $\begin{array}{c}\text { Berr. } \\
21\end{array}$ & $\begin{array}{c}\text { Berr. } \\
33\end{array}$ & $\begin{array}{c}\text { Berr. } \\
33\end{array}$ & $\begin{array}{c}\text { Berr. } \\
33\end{array}$ & $\begin{array}{c}\text { Berr. } \\
27\end{array}$ & $\begin{array}{c}\text { Berr. } \\
26\end{array}$ \\
\hline Bathysiphon spp. & A & A & $\mathrm{C}$ & $\mathrm{C}$ & & $\mathrm{F}$ & $\mathbf{R}$ & $\mathbf{R}$ & & F & $\mathrm{C}$ \\
\hline Rhizammina spp. & A & A & A & A & C & A & $\mathrm{A}$ & C & $\mathrm{C}$ & $\mathrm{C}$ & A \\
\hline Glomospira charoides & A & $\mathrm{C}$ & $\mathrm{C}$ & A & C & A & A & A & A & A & A \\
\hline Glomospirella gaultina & & & & & $\mathrm{R}$ & & & & & $\mathbf{R}$ & \\
\hline Glomospira irregularis & & $\mathrm{R}$ & $\mathbf{R}$ & $\mathrm{F}$ & $\mathbf{R}$ & & $\mathrm{R}$ & $\mathbf{R}$ & $\mathrm{R}$ & & F \\
\hline Ammodiscus cretaceus & & & $\mathbf{R}$ & & & & $\mathrm{R}$ & $\mathrm{R}$ & $\mathrm{R}$ & & \\
\hline \multicolumn{12}{|l|}{ Lituotuba spp. } \\
\hline Glomospira sp. aff. G. serpens & & & $\mathrm{R}$ & & & & $\mathbf{R}$ & & $\mathrm{R}$ & & \\
\hline Glomospira gordialis & $\mathrm{C}$ & $\mathrm{F}$ & $\mathrm{C}$ & $\mathrm{C}$ & $\mathbf{R}$ & $\mathrm{C}$ & $\mathrm{C}$ & $\mathrm{C}$ & $\mathrm{F}$ & $\mathbf{R}$ & $\mathrm{C}$ \\
\hline Reophax duplex & $\mathbf{R}$ & & $\mathrm{R}$ & $\mathbf{R}$ & $\mathrm{R}$ & & $\mathbf{R}$ & & F & & $\mathrm{F}$ \\
\hline Ammodiscus tenuissimus & $\mathrm{C}$ & $\mathrm{C}$ & $\mathrm{C}$ & $\mathrm{C}$ & $\mathrm{C}$ & $\mathrm{C}$ & $\mathrm{C}$ & A & $\mathrm{F}$ & $\mathrm{C}$ & $\mathrm{F}$ \\
\hline \multicolumn{12}{|l|}{ Glomospira sp. aff. G. diffundens } \\
\hline Ammodiscus sp. A (wide whorl) & & & $\mathrm{R}$ & & & & & & $\mathrm{R}$ & & \\
\hline Lagenammina spp. & $\mathbf{R}$ & & & $\mathbf{R}$ & $\mathbf{R}$ & & & & $\mathbf{R}$ & & \\
\hline \multicolumn{12}{|l|}{ Dendrophrya latissima } \\
\hline Rhabdammina spp. & & & $\mathrm{F}$ & $\mathrm{C}$ & & & & & $\mathrm{F}$ & & \\
\hline Hippocrepina depressa & $\mathbf{R}$ & $\mathrm{F}$ & $\mathrm{F}$ & $\mathrm{C}$ & $\mathrm{F}$ & $\mathrm{F}$ & $\mathbf{R}$ & & $\mathbf{R}$ & $\mathrm{R}$ & $\mathrm{F}$ \\
\hline Subreophax spp. & & & & $\mathbf{R}$ & & & & $\mathbf{R}$ & & & \\
\hline Saccammina sp. & $\mathbf{R}$ & $\mathbf{R}$ & & $\mathrm{R}$ & $\mathrm{F}$ & $\mathrm{C}$ & $\mathbf{R}$ & & $\mathrm{C}$ & $\mathbf{R}$ & $\mathbf{R}$ \\
\hline Paratrochamminoides spp. & & $\mathbf{R}$ & $\mathrm{R}$ & $\mathrm{R}$ & & & $\mathbf{R}$ & $\mathbf{R}$ & & $\mathrm{F}$ & $\mathbf{R}$ \\
\hline Paratrochammina spp. & & & $\mathbf{R}$ & $\mathrm{F}$ & $\mathrm{F}$ & $\mathrm{C}$ & $\mathbf{R}$ & $\mathbf{R}$ & $\mathrm{R}$ & & \\
\hline Haplophragmoides sp. A (flat) & & $\mathrm{F}$ & $\mathrm{F}$ & $\mathrm{F}$ & & & & & $\mathbf{R}$ & & \\
\hline Hormosina crassa & & $\mathbf{R}$ & & $\mathrm{R}$ & & & $\mathrm{C}$ & & $\mathbf{R}$ & & $\mathbf{R}$ \\
\hline Reophax helveticus & $\mathbf{R}$ & & $\mathbf{R}$ & $\mathrm{F}$ & $\mathrm{F}$ & $\mathrm{F}$ & $\mathrm{F}$ & $\mathrm{F}$ & $\mathrm{C}$ & F & $\mathrm{F}$ \\
\hline Spiroplectammina sp. & $\mathrm{R}$ & & & $\mathrm{R}$ & & & & & $\mathrm{R}$ & & \\
\hline \multicolumn{12}{|l|}{ Gaudryina sp. A (coarse) } \\
\hline \multirow{2}{*}{\multicolumn{12}{|c|}{ Praedorothia praehauteriviana }} \\
\hline & & & & & & & & & & & \\
\hline Verneuilinoides sp. (slender) & & & & & & & $\mathrm{C}$ & $\mathrm{C}$ & $\mathrm{F}$ & $\mathrm{F}$ & $\mathbf{R}$ \\
\hline Hyperammina dilatata & & & & $\mathrm{R}$ & & $\mathbf{R}$ & $\mathrm{F}$ & & & $\mathrm{F}$ & \\
\hline Arenoturrispirilina jeletzkyi & $\mathrm{R}$ & & $\mathbf{R}$ & $\mathbf{R}$ & $\mathrm{R}$ & $\mathrm{R}$ & $\mathrm{R}$ & & & & \\
\hline Bulbobaculites inconstans & $\mathrm{R}$ & $\mathrm{R}$ & & & $\mathrm{F}$ & $\mathrm{C}$ & $\mathrm{C}$ & $\mathbf{R}$ & & & \\
\hline Trochammina abrupta & & $\mathrm{F}$ & $\mathrm{C}$ & $\mathrm{C}$ & $\mathrm{F}$ & $\mathrm{C}$ & A & $\mathrm{C}$ & $\mathrm{F}$ & $\mathbf{F}$ & $\mathrm{F}$ \\
\hline Ammobaculoides sp. & & & & & & & & C & $\mathrm{C}$ & $\mathrm{F}$ & $\mathbf{R}$ \\
\hline Hyperammina spp. & & & & $\mathrm{R}$ & & & $\mathrm{R}$ & & & & \\
\hline "Ammodiscus sp. B (coarse, irreg. flat)" & $\mathbf{R}$ & $\mathbf{R}$ & $\mathrm{R}$ & $\mathrm{F}$ & & & & $\mathbf{R}$ & & & \\
\hline Verneuilinoides neocomiensis & $\mathrm{F}$ & $\mathrm{C}$ & $\mathrm{R}$ & $\mathrm{C}$ & $\mathrm{R}$ & A & $\mathrm{C}$ & $\mathrm{A}$ & $\mathrm{C}$ & $\mathrm{C}$ & $\mathrm{C}$ \\
\hline (?)Praecystammina sp. & $\mathbf{R}$ & & & & & & & $\mathbf{R}$ & & & $\mathbf{R}$ \\
\hline Praedorothia sp. A (smooth) & $\mathrm{R}$ & $\mathbf{R}$ & $\mathrm{R}$ & $\mathrm{C}$ & $\mathrm{F}$ & $\mathbf{R}$ & & $\mathbf{R}$ & $\mathrm{R}$ & $\mathrm{F}$ & $\mathrm{F}$ \\
\hline Kalamopsis sp. aff. $K$. grzybowskii & $\mathrm{R}$ & & & & & & & & $\mathrm{R}$ & & \\
\hline Recurvoides sp. A (smooth) & & $\mathbf{R}$ & $\mathrm{R}$ & & $\mathbf{R}$ & & $\mathrm{F}$ & $\mathrm{C}$ & $\mathrm{R}$ & & \\
\hline Praedorothia sp. B (biserial) & $\mathrm{F}$ & $\mathrm{F}$ & $\mathrm{C}$ & $\mathrm{C}$ & $\mathrm{R}$ & & $\mathrm{F}$ & C & $\mathrm{F}$ & C & C \\
\hline Haplophragmoides kirki & & $\mathrm{R}$ & & $\mathbf{R}$ & & $\mathbf{R}$ & & $\mathbf{R}$ & $\mathrm{F}$ & C & $\mathrm{C}$ \\
\hline Pseudoreophax cisownicensis & & $\mathrm{R}$ & & & & $\mathrm{C}$ & & $\mathrm{C}$ & & $\mathrm{C}$ & $\mathrm{C}$ \\
\hline Gaudryina filiformis & & $\mathrm{R}$ & & & & & $\mathrm{C}$ & $\mathbf{R}$ & $\mathrm{R}$ & & \\
\hline Turritellella sp. & & $\mathrm{R}$ & & & & & & & & & \\
\hline Bigenerina sp. & & $\mathrm{R}$ & & & $\mathrm{F}$ & $\mathrm{F}$ & $\mathrm{F}$ & $\mathrm{R}$ & & & $\mathbf{R}$ \\
\hline Aschemocella spp. & & & & $\mathbf{R}$ & & & & & & & \\
\hline Trochammina quinqueloba & & & & $\mathrm{C}$ & $\mathrm{F}$ & & & C & & $\mathrm{F}$ & $\mathbf{R}$ \\
\hline Haplophragmoides sp. B (five-chamb. round) & & & & $\mathrm{F}$ & & $\mathrm{F}$ & R & & & $\mathbf{R}$ & $\mathbf{R}$ \\
\hline Pseudobolivina spp. & & & & $\mathbf{R}$ & $\mathrm{C}$ & & $\mathrm{F}$ & $\mathbf{R}$ & & $\mathbf{R}$ & \\
\hline "Trochammina abrupta, (low-spired)" & & & & & $\mathrm{R}$ & & $\mathrm{C}$ & $\mathrm{C}$ & $\mathrm{R}$ & $\mathrm{F}$ & \\
\hline Textularia sp. (coarse) & & & & & & $\mathrm{F}$ & & & & & \\
\hline "Recurvoides sp. B (coarse, 5 chamb)" & & & & & & $\mathrm{R}$ & $\mathbf{R}$ & $\mathrm{F}$ & & $\mathbf{R}$ & $\mathrm{C}$ \\
\hline "Eggerella sp. (coarse, flaring)" & & & & & & & $\mathrm{R}$ & & & & \\
\hline "Haplophragmoides sp. C (thick, convex)" & & & & & & & $\mathbf{R}$ & & & & \\
\hline Ammodiscus sp. C (robust) & & & & & & & & $\mathbf{R}$ & & & \\
\hline Haplophragmoides sp. (broad) & & & & & & & & $\mathrm{R}$ & & & \\
\hline Hormosinella sp. & & & & & & & & $\mathrm{R}$ & & & \\
\hline Trochamminoides sp. & & & & & & & & $\mathrm{R}$ & & & \\
\hline Uvigerinammina spp. & & & & & & & & & $\mathrm{R}$ & $\mathrm{F}$ & \\
\hline Psammosphaera fusca & & & & & & & & & $\mathrm{R}$ & & \\
\hline Glomospirella (Annectina) sp. & & & & & & & & & & $\mathbf{R}$ & \\
\hline Hormosina excelsa & & & & & & & & & & & $\mathbf{R}$ \\
\hline Hormosina cf. crassa & & & & & & & & & & & \\
\hline Reophax sp. B (globular chamber) & & & & & & & & & & & \\
\hline Marssonella sp. (conical) & & & & & & & & & & & \\
\hline Ammolagena clavata & & & & & & & & & & & \\
\hline Haplophragmoides sp. D (flat evolute) & & & & & & & & & & & \\
\hline Reophax sp. C (coarse) & & & & & & & & & & & \\
\hline "Trochammina sp. A (large, biconvex)" & & & & & & & & & & & \\
\hline Ammobaculites sp. (coarse) & & & & & & & & & & & \\
\hline Ammodiscoides sp. & & & & & & & & & & & \\
\hline
\end{tabular}


APPENDIX A (continued).

\begin{tabular}{|c|c|c|c|c|c|c|c|c|c|c|}
\hline Core: & $61 R-2$ & $61 \mathrm{R}-4$ & $61 R-5$ & 61R-CC & $62 \mathrm{R}-1$ & $62 \mathrm{R}-1$ & $62 R-2$ & $62 \mathrm{R}-3$ & $62 R-3$ & $62 \mathrm{R}-4$ \\
\hline Interval $(\mathrm{cm})$ : & $96-100$ & $61-63$ & $58-60$ & & $53-56$ & $90-91$ & $138-142$ & $95-96$ & $138-142$ & $25-27$ \\
\hline Depth (mbsf): & 919.4 & 922 & 923.5 & 926.4 & 926.9 & 927.3 & 929.2 & 930.3 & 930.8 & 931.6 \\
\hline Age: & Berr. & Tith. & Tith. & Tith. & Tith. & Tith. & (?)Tith. & (?)Tith. & (?)Tith. & (?)Tith. \\
\hline No. of species & 27 & 22 & 22 & 33 & 13 & 7 & 15 & 13 & 18 & 18 \\
\hline Bathysiphon spp. & $\mathrm{F}$ & & $\mathrm{F}$ & & & R & $\mathbf{R}$ & $\mathrm{R}$ & C & C \\
\hline Rhizammina spp. & A & C & C & $\mathrm{C}$ & $\mathrm{F}$ & & $\mathrm{C}$ & $\mathbf{F}$ & C & C \\
\hline Glomospira charoides & A & A & A & $\mathrm{C}$ & C & A & C & A & A & C \\
\hline Glomospirella gaultina & $\mathrm{R}$ & & & & & & & & & \\
\hline Glomospira irregularis & $\mathrm{R}$ & $\mathrm{F}$ & & $\mathbf{R}$ & & & & & & \\
\hline Ammodiscus cretaceus & & & & $\mathrm{R}$ & & & & & & \\
\hline \multicolumn{11}{|l|}{ Lituotuba spp. } \\
\hline Glomospira sp. aff. G. serpens & & & & $\mathrm{R}$ & & & & & & \\
\hline Glomospira gordialis & C & $\mathrm{C}$ & $\mathrm{C}$ & & & $\mathrm{F}$ & $\mathrm{F}$ & & $\mathrm{F}$ & $\mathbf{R}$ \\
\hline Reophax duplex & $\mathrm{R}$ & & & & & & & & & \\
\hline Ammodiscus tenuissimus & $\mathrm{F}$ & $\mathrm{C}$ & A & A & $\mathbf{R}$ & & $\mathrm{C}$ & $\mathrm{F}$ & $\mathrm{C}$ & $\mathrm{C}$ \\
\hline \multicolumn{11}{|l|}{ Glomospira sp. aff. $G$. diffundens } \\
\hline Ammodiscus sp. A (wide whorl) & & & $\mathbf{R}$ & $\mathrm{R}$ & & & & & & \\
\hline Lagenammina spp. & & & & $\mathbf{R}$ & & & & & & \\
\hline \multicolumn{11}{|l|}{ Dendrophrya latissima } \\
\hline Rhabdammina spp. & $\mathrm{F}$ & & & $\mathrm{F}$ & & $\mathrm{R}$ & $\mathbf{R}$ & & $\mathbf{R}$ & \\
\hline Hippocrepina depressa & & $\mathrm{R}$ & & $\mathrm{R}$ & & & $\mathbf{R}$ & & F & $\mathrm{F}$ \\
\hline Subreophax spp. & & $\mathrm{R}$ & & & & & & & & \\
\hline Saccammina sp. & & & $\mathrm{F}$ & & & & & & & \\
\hline Paratrochamminoides spp. & $\mathrm{R}$ & & & & & & & & & \\
\hline Paratrochammina spp. & & $\mathrm{F}$ & $\mathbf{R}$ & & & & & & & \\
\hline \multicolumn{11}{|l|}{ Haplophragmoides sp. A (flat) } \\
\hline Hormosina crassa & $\mathrm{F}$ & $\mathrm{F}$ & $\mathrm{C}$ & $\mathrm{R}$ & & & & & & \\
\hline Reophax helveticus & C & $\mathrm{R}$ & $\mathrm{R}$ & & & & & & & \\
\hline Spiroplectammina sp. & & $\mathrm{R}$ & $\mathrm{R}$ & & & & & & & \\
\hline \multicolumn{11}{|l|}{ Gaudryina sp. A (coarse) } \\
\hline Psammosphaera sp. & & & $\mathbf{R}$ & $\mathrm{F}$ & $\mathrm{F}$ & $\mathrm{C}$ & $\mathrm{C}$ & C & C & C \\
\hline Praedorothia praehauteriviana & & & & & & & & & & \\
\hline Verneuilinoides sp. (slender) & $\mathrm{F}$ & $\mathrm{F}$ & & $\mathrm{F}$ & & & R & $\mathrm{F}$ & F & $\mathrm{F}$ \\
\hline Hyperammina dilatata & & & & & & & & & & \\
\hline Arenoturrispirilina jeletzkyi & $\mathrm{R}$ & & $\mathbf{R}$ & & & & & & & \\
\hline Bulbobaculites inconstans & A & $\mathrm{F}$ & $\mathrm{C}$ & $\mathrm{C}$ & $\mathrm{F}$ & & & & $\mathrm{F}$ & $\mathrm{F}$ \\
\hline Trochammina abrupta & C & A & C & $\mathrm{C}$ & & C & $\mathrm{C}$ & C & A & \\
\hline Ammobaculoides sp. & & & & $\mathrm{R}$ & & & & & & \\
\hline Hyperammina spp. & $\mathrm{R}$ & R & $\mathrm{R}$ & $\mathrm{R}$ & & & & & & $\mathbf{R}$ \\
\hline "Ammodiscus sp. B (coarse, irreg. flat)" & & & & & & & & & & $\mathbf{R}$ \\
\hline Verneuilinoides neocomiensis & & & $\mathrm{R}$ & & $\mathrm{F}$ & & & & & \\
\hline (?)Praecystammina sp. & & & & & & & & & & \\
\hline Praedorothia sp. A (smooth) & $\mathrm{F}$ & $\mathrm{F}$ & & & & & & & & \\
\hline Kalamopsis sp. aff. $K$, grzybowskii & & & & & & & & & & \\
\hline Recurvoides sp. A (smooth) & & & $\mathrm{R}$ & $\mathrm{R}$ & & & & $\mathrm{R}$ & F & \\
\hline Praedorothia sp. B (biserial) & R & & & $\mathrm{F}$ & & & & & & \\
\hline Haplophragmoides kirki & C & & & & & & & & & $\mathrm{F}$ \\
\hline Pseudoreophax cisownicensis & & & & $\mathrm{R}$ & & & & & & \\
\hline Gaudryina filiformis & & & & & & & & & & \\
\hline Turritellella sp. & R & & & & & & & & & \\
\hline Bigenerina sp. & & $\mathrm{R}$ & & $\mathrm{C}$ & $R$ & & & & & \\
\hline Aschemocella spp. & $\mathbf{R}$ & & & & & & $\mathbf{R}$ & & & \\
\hline Trochammina quinqueloba & $\mathrm{F}$ & $\mathrm{F}$ & $\mathrm{R}$ & $\mathrm{F}$ & $\mathbf{R}$ & & C & A & A & A \\
\hline Haplophragmoides sp. B (five-chamb. round) & & & $\mathbf{F}$ & $\mathbf{R}$ & & & & & & \\
\hline Pseudobolivina spp. & & & F & $\mathbf{R}$ & & & & & & $\mathrm{F}$ \\
\hline "Trochammina abrupta, (low-spired)" & & & & $\vec{R}$ & & & & $\mathrm{~F}$ & C & \\
\hline Textularia sp. (coarse) & & & & & & & & & & \\
\hline "Recurvoides sp. B (coarse, 5 chamb)" & & & & & $\mathbf{R}$ & & & & & \\
\hline "Eggerella sp. (coarse, flaring)" & & & & & & & & & & \\
\hline "Haplophragmoides sp. C (thick, convex)" & & & & & & & & & & \\
\hline Ammodiscus sp. C (robust) & & & & & & & & & & $\mathbf{R}$ \\
\hline Haplophragmoides sp. (broad) & & & & & & & & & & \\
\hline Hormosinella sp. & & & & 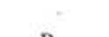 & & & & & & \\
\hline Trochamminoides sp. & & & & $\mathbf{R}$ & & & & & & \\
\hline Uvigerinammina spp. & $\mathrm{C}$ & & & $\mathrm{C}$ & $\mathbf{R}$ & & & & & R \\
\hline Psammosphaera fusca & & & & $\mathrm{F}$ & $\mathbf{R}$ & & & $\mathbf{R}$ & $\mathrm{F}$ & \\
\hline Glomospirella (Annectina) sp. & & & & & & & & & & \\
\hline Hormosina excelsa & $\mathrm{R}$ & & & & & & & & & \\
\hline Hormosina cf. crassa & $\mathrm{F}$ & $\mathrm{F}$ & & & & & & & & \\
\hline Reophax sp. B (globular chamber) & $\mathrm{F}$ & & & & & & & & & \\
\hline Marssonella sp. (conical) & & C & $\mathrm{F}$ & $\mathbf{R}$ & & $\mathbf{R}$ & & & & \\
\hline Ammolagena clavata & & $\mathbf{R}$ & $\mathbf{R}$ & $\mathbf{R}$ & & & $\mathrm{F}$ & & $\mathbf{R}$ & \\
\hline Haplophragmoides sp. D (flat evolute) & & & & $\mathrm{F}$ & $\mathrm{F}$ & & $\mathrm{R}$ & & & \\
\hline Reophax sp. C (coarse) & & & & $R$ & $R$ & & & R & & \\
\hline "Trochammina sp. A (large, biconvex)" & & & & & & & $\mathrm{F}$ & $\mathrm{F}$ & C & $\mathbf{R}$ \\
\hline Ammobaculites sp. (coarse) & & & & & & & & & $\mathbf{R}$ & \\
\hline Ammodiscoides sp. & & & & & & & & & & $\mathrm{F}$ \\
\hline
\end{tabular}


APPENDIX B

Calcareous Benthic Foraminifers

\begin{tabular}{|c|c|c|c|c|}
\hline \multirow[b]{2}{*}{ Species } & \multicolumn{4}{|c|}{ Sample } \\
\hline & $\begin{array}{c}56 R-4 \\
144-148\end{array}$ & 56R-CC & $\begin{array}{l}58 \mathrm{R}-2 \\
10-14\end{array}$ & $\begin{array}{l}61 R-5 \\
58-60\end{array}$ \\
\hline Vaginulinopsis humilis (Reuss) & $\mathrm{F}$ & & & \\
\hline Lenticulina spp. & $\mathrm{C}$ & C & $\mathrm{F}$ & \\
\hline Lingulina loryi (Berthelin) & $\mathrm{R}$ & & & \\
\hline $\begin{array}{l}\text { Gavellinella bettenstaedti Dieni and } \\
\text { Massari }\end{array}$ & $\mathbf{R}$ & & & \\
\hline Lenticulina subalata (Reuss) & $\mathbf{R}$ & & & \\
\hline Lenticulina muensteri (Reomer) & $\mathrm{F}$ & & $\mathbf{R}$ & $\mathrm{F}$ \\
\hline Lenticulina guttata (Ten Dam) & $\mathbf{R}$ & & & \\
\hline Vaginulopsis reticulosa Ten Dam & $\mathbf{R}$ & & & \\
\hline Dentalina spp. & $\mathrm{F}$ & & $\mathrm{F}$ & $\mathbf{R}$ \\
\hline Ramulina aculeata Wright & $\mathbf{R}$ & $\mathbf{R}$ & & \\
\hline Nodosaria sp. & $\mathrm{F}$ & & & \\
\hline Vaginulina sp. & $\mathrm{R}$ & & & \\
\hline Gavellinella sp. & $\mathrm{R}$ & & & \\
\hline Lenticulina sp. aff. L. saxonica & & $\mathbf{R}$ & & \\
\hline Lenticulina ouachensis (Sigal) & & $\mathbf{R}$ & & \\
\hline Paalzowella feifeli (Paalzow) & & $\mathrm{F}$ & $\mathbf{R}$ & $\mathrm{F}$ \\
\hline Epistomina caracolla (Roemer) & & $\mathrm{R}$ & & \\
\hline Pyrulina longa Tappan & & $\mathrm{F}$ & & \\
\hline Citharina sp. & & $\mathrm{R}$ & $\mathbf{R}$ & $\mathbf{F}$ \\
\hline Lenticulina sp. aff. L. nodosa (Reuss) & & & $\mathbf{R}$ & $\mathrm{R}$ \\
\hline Lingulina semiornata Reuss & & & $\mathbf{R}$ & $\mathbf{R}$ \\
\hline
\end{tabular}

APPENDIX C

Barren Samples from Hole 765C

\begin{tabular}{|c|c|c|c|}
\hline Sample & Interval $(\mathrm{cm})$ & Sample & Interval $(\mathrm{cm})$ \\
\hline $42 \mathrm{R}-2$ & $66-68$ & $53 R-3$ & $100-104$ \\
\hline $42 \mathrm{R}-\mathrm{CC}$ & & $53 R-4$ & $78-82$ \\
\hline 43R-CC & & 53R-6 & $47-51$ \\
\hline $44 \mathrm{R}-1$ & 93-97 & 53R-CC & \\
\hline $44 R-4$ & $19-23$ & $54 \mathrm{R}-1$ & $135-139$ \\
\hline $44 R-4$ & $34-38$ & $54 \mathrm{R}-3$ & $41-43$ \\
\hline $44 \mathrm{R}-\mathrm{CC}$ & & $54 \mathrm{R}-4$ & $137-141$ \\
\hline $45 R-3$ & $84-88$ & $55 \mathrm{R}-3$ & $146-150$ \\
\hline $45 R-C C$ & & $55 \mathrm{R}-4$ & $22-26$ \\
\hline $46 \mathrm{R}-1$ & $116-121$ & 55R-CC & \\
\hline $46 \mathrm{R}-2$ & $26-29$ & $56 \mathrm{R}-1$ & $110-114$ \\
\hline $46 \mathrm{R}-\mathrm{CC}$ & & $56 \mathrm{R}-2$ & $122-126$ \\
\hline $47 R-2$ & $21-24$ & $56 \mathrm{R}-3$ & $49-53$ \\
\hline $47 \mathrm{R}-2$ & $47-51$ & $57 \mathrm{R}-1$ & $44-48$ \\
\hline $47 R-4$ & $0-6$ & $57 \mathrm{R}-5$ & $45-48$ \\
\hline $47 \mathrm{R}-\mathrm{CC}$ & & $57 \mathrm{R}-5$ & $87-90$ \\
\hline $48 \mathrm{R}-2$ & $27-28$ & $57 \mathrm{R}-6$ & $118-121$ \\
\hline $48 \mathrm{R}-2$ & $102-106$ & $57 R-7$ & $0-2$ \\
\hline $48 R-4$ & $47-51$ & $58 \mathrm{R}-1$ & $132-137$ \\
\hline $48 \mathrm{R}-\mathrm{CC}$ & & $58 \mathrm{R}-2$ & $65-67$ \\
\hline $49 \mathrm{R}-1$ & $64-67$ & $58 \mathrm{R}-3$ & $89-93$ \\
\hline $49 \mathrm{R}-\mathrm{CC}$ & & $58 \mathrm{R}-5$ & $89-93$ \\
\hline $50 \mathrm{R}-4$ & $76-78$ & $59 \mathrm{R}-1$ & $66-68$ \\
\hline $50 \mathrm{R}-5$ & $32-34$ & $59 \mathrm{R}-1$ & $123-126$ \\
\hline $51 \mathrm{R}-2$ & $20-24$ & $59 \mathrm{R}-4$ & $86-90$ \\
\hline $52 \mathrm{R}-2$ & $72-76$ & $61 R-4$ & $91-93$ \\
\hline $52 \mathrm{R}-2$ & $118-122$ & & \\
\hline $52 \mathrm{R}-3$ & $57-61$ & & \\
\hline \multicolumn{4}{|l|}{$52 \mathrm{R}-\mathrm{CC}$} \\
\hline $53 \mathrm{R}-1$ & $63-67$ & & \\
\hline
\end{tabular}

